\title{
Dış Politikada Ulusal Güvenliğin Tahakkümü: İsrail'in Doğu Akdeniz Politikasında Militarizm
}

\author{
Ceyhun Çiçekçi*
}

\section{$\ddot{O} \mathbf{z}$}

Son on y1l boyunca İsrail, Türkiye'nin desteğini kaybetmek pahasına, Doğu Akdeniz'de politik güzergahını değiştirerek Yunanistan ve Güney Kıbrıs Rum Yönetimi'yle müttefik oldu. Söz konusu ittifak, genel olarak, 2009-2011 y1llarında bölgede keşfedilen gaz rezervleriyle açıklandı. Fakat troyka, politik olarak kullanışlı ve masum açıklamaların aksine, gerçek bir askeri ittifakın parçası oldular. Buna göre, enerji diplomasisi, ilişkilerinin özünü örtebilmek için kullanıldı. Bu çalı̧̧ma öncelikle dış politika-ulusal güvenlik ilişkilerini kavramsal bir anlayışla analiz etmektedir. Sonrasında, İsrail'in dışişlerindeki ulusal güvenlik tahakkümüne dair temel argümanını test edebilmek için İsrail dış politikasının ayırt edici vakaları incelenmektedir. Çalışma, son olarak Ocak 2020'de imzalanan Doğu Akdeniz Boru Hattı anlaşmasına kadar geçen süredeki askeri gelişmeleri değerlendirerek, troykanın askeri ittifakını ortaya koymayı hedeflemektedir. Çalışmanın izlediği bu metodoloji, kuşkusuz bahsi geçen askeri ittifakın gerçek yüzünü ve sivil bir girişim olmadığını gösterecektir.

Keywords: Dış Politika, Ulusal Güvenlik, Militarizm, İsrail, Doğu Akdeniz

Öğr. Gör. Dr., Bandırma Onyedi Eylül Üniversitesi, TR, Erdek Meslek Yüksek Okulu, Yerel Yönetimler Program1, orcid.og/0000-0002-5036-537X, ccicekci@bandirma.edu.tr 


\title{
The Dominance of National Security in Foreign Policy: Militarism in Israel's East Mediterranean Policy
}

\author{
Ceyhun Çiçekçi*
}

\begin{abstract}
Throughout the last decade, Israel changed its political path in the East Mediterranean and allied with Greece and the Greek Administration of Southern Cyprus at the expense of losing Turkey's support. This alliance is generally explained by gas reserves which were explored in 2009- 2011 across the region. However, the troika has in fact been in a military alliance contradicting politically useful and "innocent" explanations. Accordingly, energy diplomacy has been used to cover the essence of this relationship. This study firstly analyzes foreign policynational security relations in a conceptual manner. Then, some selective cases of Israeli foreign policy will be examined in order to test the main argument of this study that national security dominates Israeli foreign policy. Lastly, this study aims at debunking the military alliance among the troika by pointing out the military events that took place until the signing of the EastMed Pipeline Deal in January 2020. In this way, the study will surely unearth the real nature of such a military alliance and that this alliance is not a civilian enterprise.
\end{abstract}

Keywords: Foreign Policy, National Security, Militarism, Israel, East Mediterranean

* Dr. Lecturer, Bandirma Onyedi Eylul University, TR, Erdek Vocational School, Local Governments Program, orcid.og/0000-0002-5036-537X, ccicekci@bandirma.edu.tr 


\section{Giriş}

Bir süredir Doğu Akdeniz bölgesinin kıyıdaş ülkelerde ve uluslararası kamuoyunda gündemde olduğu gözlemlenmektedir. Hatta denilebilir ki Doğu Akdeniz, bu süreçte "bir bölge" hüviyetine kavuşmaktadır. Yakın geçmişte bağımsız bir alt-sistem olarak pek ismi duyulmayan bu bölge, bugün artık ilgili ülkelerin ulusal güvenlik ve dış politika gündemlerinde oldukça üst sıralara taşınmış durumdadır.

Doğu Akdeniz'i bölgeselleştiren temel unsur, hiç kuşkusuz son on yılda bu bölgenin çeşitli noktalarında keşfedilen enerji kaynaklarıdır. Keşfedilmiş ve ispat edilmiş doğalgaz rezervleri, yeni rezervlerin olasılığını güçlendirdiği için bölge ve bölge dişı ülkelerin de dikkatini bu yöne çevirmesine sebep olmuştur. Böylece Doğu Akdeniz, bağımsız bir gündemle uluslararası projelerin ve politikaların da merkezine oturmuştur.

İsrail' in Doğu Akdeniz politikası, bugüne kadar üzerinde pek durulmayan bir konu başlı̆ğ olmuştur. Daha ziyade Filistin sorunu ve İran "tehdidi" bağlamında gündeme gelen İsrail, uluslararası kamuoyunun dikkatini artık Doğu Akdeniz'deki konumuyla da çekmektedir. Bu açıdan bakıldığında İsrail, kuşkusuz Doğu Akdeniz'in kritik önemdeki aktörlerinden biridir. Doğal olarak da İsrail'in bölge politikalarını akademik bir incelemeye tabi tutmak, bölge jeopolitiğini anlamlandırabilmek adına elzemdir.

Fakat böylesi bir incelemeye başlarken öncelikle İsrail dış politikasının genel seyrindeki niteliklere eğilmek de gerekmektedir. Bu bağlamda, İsrail dış politikası hakkında yapılacak bir tartışma, niteliksel olarak söz konusu dış politikanın zihinsel altyapısını ortaya çıkarmaya yarayabilir. $\mathrm{Bu}$ çalışma da öncelikle İsrail dış politikasını mercek altına almaktadır. Yoğun ulusal güvenlik gündeminin perdelemesiyle İsrail dış politikasının aslında bir savunma ve ulusal güvenlik politikası olduğu iddia edilmektedir. $\mathrm{Bu}$ bağlamda da selektif örneklerle dış politikadaki manevra alanının kısıtlılığı, bu kısıtlılığın sebepleri ve dolayısıyla ulusal güvenlik başlıklarının dış politika sahasına hakimiyeti açıklanmaktadır. Söz konusu ulusal güvenlik gündeminin başatlığ 1 ve dış politika sahasındaki hakimiyeti, görünürde bir enerji diplomasisi olarak gelişen İsrail'in Doğu Akdeniz politikasındaki hamlelerinin analiziyle örneklendirilmektedir. 


\section{Kavramsal Tartışma: Dış Politika-Ulusal Güvenlik İlişsisi}

Dış politika ile ulusal güvenlik arasında güçlü bir ilişki vardır. Hatta denilebilir ki devletler, dış politikalarını kurgularken öncelikle ulusal güvenliklerini hesaba katarak, stratejiler geliştirirler. Bu bağlamda ulusal güvenlik, dış politikanın olmazsa olmaz bir parçasıdır. ${ }^{1}$

Günümüzde akademik yayınlara göz atıldığında dahi kabaca gözlemlenebilecek başlıca husus, dış politika ile ulusal güvenlik kavramlarının bir diğeri yerine ya da birlikte sıklıkla kullanıldığıdır. $\mathrm{Bu}$ açıdan bakıldığında, dış politika ve ulusal güvenlik kavramlarının sınırlarının bulanıklaştığı ve dahi kavramsal bir netlikten uzaklaştığı iddia edilebilir.

Dış politika ile kastedilen kavramsal alan, kuşkusuz daha geniş bir içeriğe tekabül etmektedir. $\mathrm{Bu}$ bağlamda diş politika, ulusal güvenliği kapsar ve daha geniş bir çerçeve sunar. ${ }^{3}$ Ulusal güvenlik politikalarının uygulanabilmesi, ancak dış politika yaklaşımlarıyla belirgin bir uyum arz ettiğinde mümkün olabilir.

Bir devletin dış politikası, her şeyden önce egemenlik sahasının dışında kalan kısımla ilişkilerine işaret eder. Bir diğer ifadeyle diş politika, devletlerin sınırları ötesindeki dünyayla ilişkilerini biçimlendirmeye yarar. Devletler, kurguladıkları ve uyguladıkları dış politika söylem ve pratikleriyle birlikte uluslararası politikada birer özne olarak kendilerini ifade ederler. ${ }^{4}$ Bir özne olarak devletin kimliğini ve çıkarlarını dış politika davranışları üzerinden tespit edebilmek mümkündür. Bu bağlamda dış politika, devletlerin, sistemin parçası birer üniteler olarak, uluslararası politikadaki etkileşimlerinin tümüdür ve tanımlayıcı bir öğesidir. ${ }^{5}$

Jean Frederic Morin ve Jonathan Paquin, Foreign Policy Analysis: A Toolbox (Cham: Palgrave Macmillan, 2018), 5-6.

2 Bu durumun örneği olabilecek çok sayıda yayına literatürde rastlanabilir. Bir örnek için bknz. Melvyn P. Leffler, Safeguarding Democratic Capitalism: U.S. Foreign Policy and National Security 1920-2015 (New Jersey: Princeton University Press, 2017). Ayrıca özellikle AB'nin bu bağlamdaki girişimleri de etkili olmuştur. Bknz. "Foreign and Security Policy," European Union Official Website, Son erişim: 17 Ekim 2020, https://europa.eu/european-union/topics/foreign-security-policy_en.

3 Laura Neack, Studying Foreign Policy Comparatively: Cases and Analysis (Maryland: Rowman \& Littlefield, 2019), 7.

4 Morin ve Paquin, Foreign Policy Analysis, 4.

$5 \quad$ M. Fatih Tayfur, "Dış Politika," içinde Devlet ve Ötesi: Uluslararası Illişkilerde Temel Kavramlar, ed. Atila Eralp (İstanbul: İletişim Yayınları, 2007), 74. 
Dış politikayla ulusal güvenlik arasındaki ilişki ise her iki kavramın da oldukça geniş bir anlam çeşitliliğine sahip olmasından dolayı tanımlaması zor bir olgudur. Her ne kadar dış politika ulusal güvenliği de kapsayan bir içerik sunsa da her iki kavramın da devlet organizasyonu içerisinde sahiplenen kurumları farklıdır. Dış politika alanıyla dışişleri bakanlıkları yetkilendirilirken ulusal güvenlik konuları için ise ekseriyetle savunma bakanlıkları görevlendirilir. ${ }^{6} \mathrm{Bu}$ bağlamda, dış politikanın görece sivil bir alan olduğu da tespit edilebilir. Savunma bakanlıklarının, genel olarak, askeri güvenlik konularıyla ilgilerini sınırlı tutmaları, dışişleri bakanlıklarının ise dış dünyayla iletişimden sorumlu olmaları genel kabul gören organizasyonel yaklaşımlardır. Ayrıca her iki alanda da profesyonellik ön plana çıkar ve diplomatlarla subaylardan oluşan bürokratik bir yapılanma söz konusudur. Her iki alanı da yönlendirecek olan siyasi irade olsa da nihai kertede ilgili politikaların uygulanmasında icracı statüde söz konusu profesyonel kadrolar görev alır.

Kaldı ki dış politikanın ve ulusal güvenlik politikalarının araçları da birbirinden oldukça farklıdır. Dış politika sahasında ekseriyetle sivil diplomatik faaliyetler ön plana çıkarken ulusal güvenlik politikalarının merkezinde askeri yaklaşımlar yer tutar. Uluslararası politikanın da temel dinamiği olarak diplomasi, bizatihi ulusal güvenlik politikalarının askeri tabiatından kaynaklanabilecek olası savaşları önleyebilmek üzere kendini meşrulaştırır. Bir diğer ifadeyle dış politika ve onun temel aracı olarak diplomasi, ordulara gerek kalmaksızın uluslararası politikadaki sorunların hallini önceler ve hayata geçirir.

Fakat nihayetinde orduların bir dış politika aracı olarak kullanılması da mümkündür. Daha ziyade zorlayıcı diplomasi olarak bilinen uygulama sahası, askeri gücün bir biçimde devreye sokularak, muhatap ülkenin diş politika davranışlarının değiştirilmesini amaçlar. Bu yöntem de kuşkusuz, dış politikanın ulusal güvenlik politikalarıyla kesiştiği gri bir alanı tarif eder.

İsrail kontekstinde ulusal güvenlik konularıla ilgilenen birden fazla bakanlık bulunmaktadır. Bu bağlamda, Savunma Bakanlığı'nın yanı sıra İstihbarat Bakanlığı, Kamu Güvenliği Bakanlığı ve Stratejik İşler Bakanlığı da ulusal güvenlik konularıyla ilgili çalışmalar yapmaktadır. Bknz. The Knesset Official Website, Son erişim: 17 Ekim 2020, https://main.knesset.gov.il/EN/mk/government/Pages/governments. aspx?govId $=35$. 
Ulusal güvenlik alanındaki akademik literatür, kavramın tanımı itibariyle oldukça genişleyen bir spektruma sahiptir. Bugün artık hemen her şey ulusal güvenliğin alanına girebilir ve bu minval üzere birtakım uygulamalara konu olabilir. Bu açıdan bakıldığında, güvenlik çalışmalarında özellikle Soğuk Savaş'ın bitişi önemli bir kırılmayı da temsil etmektedir. ${ }^{7}$ Devletlerin ulusal güvenlik kaygılarını salt militarist bir çizgide algıladıkları ve buna istinaden pratikler geliştirdikleri bir dönem olarak Soğuk Savaş, bitişiyle birlikte oldukça farklı ve çeşitli yaklaşımları da gündeme taşımıştır.

Günümüzde güvenliği askeri, ekonomik, siyasal, toplumsal ve çevresel alt başlıklarıyla kabaca beş ayrı sektörde incelemek, genel kabul görmüş bir yaklaşım olarak bilinmektedir. ${ }^{8}$ Soğuk Savaş dönemi ve öncesine dair askeri güvenlik gündeminin başatlığ 1 , günümüzde tek başına bir anlam ifade etmemektedir. Fazlasıyla girift bir ulusal güvenlik gündemi, devletlerin kıt kaynaklarını güvenlikleştirici süreçlere aktarmalarına ve buna mukabil pratikler üretmelerine zemin hazırlamaktadır.

Güvenlik çalışmalarının temel sorunsalı olarak güvenlik kavramının semantik sınırları, erken dönem güvenlik çalışmalarına da damga vurmuş bir olgudur. Bu bağlamda güvenlik, sınırları tamamıyla bulanık ve alabildiğine genişletilebilecek bir hassasiyet taşır. ${ }^{9}$ İnsanların temel değerleri yaşamlarıdır ve bu sebeple insanlar, yaşamlarının garantisini sağlayabilmek anlamına gelen güvenlikleri uğruna hemen her şeylerinden vazgeçebilirler. $\mathrm{Bu}$ durum, güvenlik başlı̆g 1 altında değerlendirilen problemlerin diğer bütün alanlara karşı belirgin bir söylem-pratik üstünlüğü kurmasına vesile olur. Hatta devletler, güvenlikleştirme süreçleriyle insanların güvenlik algılarını istismar edebilirler. Nihayetinde güvenliğe dair kaygıların dillendirilmesi, diğer her konu başlı̆̆ına galebe çalacak bir üstünlük sağlar ve hemen her olumsuzluğu perdelemek için kullanılabilir.

Lakin devletlerin dış politikaları, ekseriyetle siviller tarafindan yönlendirilir ve sivil amaçları önemserler. Günümüzde 'yumuşak güç' olarak isimlendirilen etki kapasitesi, devletlerin herhangi bir askeri tedbire

David A. Baldwin, "Security Studies and the End of the Cold War," World Politics 48, no. 1 (Ekim 1995): 117-141.

8 Barry Buzan, Ole Weaver ve Jaap De Wilde, Security: A New Framework for Analysis (Colorado: Lynne Rienner, 1998).

9 Arnold Wolfers, “'National Security' as an Ambiguous Symbol," Political Science Quarterly 67, no. 4 (Aralik 1952): 481-502. 
gerek kalmaksızın dış politikalarındaki hedeflere ulaşmalarını simgeler. ${ }^{10}$ Her ne kadar jeopolitik dönüşüm süreçlerinde sert güç unsurları devreye girse de dış politika, bir araç olarak ekseriyetle diplomasiye yaslanır ve sivillerin diğer ülke sivillerini etki altına alması ve ülke çıkarlarını bu yolla gerçekleştirmesi temelinde hayat bulur.

Daha geniş bir çerçeveden bakıldığında dış politika sahası, ulusal ölçekteki kimliksel inşa süreçlerinin de dişavurumu olarak görülebilir. $\mathrm{Bu}$ bağlamda dış politika, kendisine biçebileceği dönüştürücü bir misyonla, dünya üzerindeki ulusların ve onları temsil eden devletlerinin kimliklerini ve dolayısıyla ulusal çıkarlarını etkilemek kaygısıyla hareket edebilir. Ahlaki bir takım önermelerle, dünya politikasına yön vermeye çalışabilir. Amerikan dış politikasının tarihinde sıklıkla karşılaşılabilecek bir olgu olarak misyoner yaklaşım, dış politikada diğer ulusları dönüştürmek ve çeşitli nitelikleri itibariyle kendine benzetmeye çalışmak yolunda atılmış adımlardan oluşur. ${ }^{11}$ İdeolojik ve siyasi benzeşmeler, askeri ve ekonomik kapasiteleri ve dolayısıyla ikili ilişkileri dönüştürecek bir zemin yaratacaktır.

Dış politika-ulusal güvenlik ilişkisi, İsrail özelinde oldukça güçlü bir örnek teşkil eder. Hatta bu çalışmanın da iddia ettiği üzere, İsrail dış politikasının varlığg dahi tartışmalıdır. İsrail devletinin bir dış politikadan ziyade savunma/ulusal güvenlik politikasına sahip olduğu mütemadiyen dillendirilen bir argümandır. Bu bağlamda İsrail dış politikası, ulusal güvenlik yaklaşımlarının etkisi altında olmaktan da öte, bu yaklaşımlarca yönlendirilen bir güzergaha sahiptir. Kaldı ki aşağıda da örneklerle ifade edileceği üzere, İsrail dış politika tarihine kuşbakışı bakıldığında, ulusal güvenlik kaygılarının dış politikayı domine ettiği ve şüpheye yer bırakmayacak ölçüde bir tahakküm kurduğu dahi iddia edilebilir.

Elbette ki ulusal güvenlik kaygılarının güçlü bir biçimde tezahürü, dış politikayı yöneten siyasal elitler nezdinde bir profil değişimine de sebep olabilir. $\mathrm{Bu}$ açıdan bakıldığında, İsrail dış politikasının dönüm noktalarında muvazzaf ya da emekli askerlerin ön plana çıktığı da sıklıkla

10 Joseph S. Nye, “Soft Power," Foreign Policy, no. 80 (Sonbahar 1990): 153-171.

11 Michael Cox, Timothy J. Lynch ve Nicholas Bouchet, US Foreign Policy and Democracy Promotion: From Theodore Roosevelt to Barack Obama (New York: Routledge, 2013), 1-13. 
gözlemlenebilir. Hatta bu tandans İsrail özelinde o denli güçlüdür ki devletin kategorik tanımlanmasını dahi olumsuzlamaya referans oluşturur. 'Garnizon Devlet' olarak adlandırılan militarist devlet yapılanmalarına İsrail' in de örnek verilmesi, pek çok akademik çalışmada karşılaşılabilecek bir durumdur. ${ }^{12}$

Yukarıdaki açıklamalara güncel bir referans olması hasebiyle, İsrail siyasetinin cari dizilimi de oldukça açıklayıcıdır. Halihazırda Netanyahu liderliğindeki İsrail hükümetinde dışişleri bakanlığını eski bir genelkurmay başkanı yürütmektedir.2007-2011 arasında Genelkurmay Başkanı olan Gabi Aşkenazi, 2008 yılının son günlerinde Gazze'ye düzenlenen ve çok sayıda sivilin öldürülmesiyle sonuçlanan Dökme Kurşun Operasyonu ve 2010 yılının Mayıs ayında uluslararası sularda hukuk dışı bir biçimde müdahale edilen ve sivillerin katline sebep olan Mavi Marmara baskını esnasında söz konusu görevini yürütmekteydi. Bu açıdan bakıldığında, Aşkenazi’nin dışişleri bakanı olarak görevlendirilmesi, her ne kadar iç siyasi dengelerin bir sonucu olarak görülebilecekse de İsrail'in dış politikasında verilmek istenen mesajı güçlendirmek amacını da gerçekleştirmiş olmaktadır. Bir diğer ifadeyle İsrail, sivillerin katline cevaz vermiş eski bir genelkurmay başkanını dış politikasının yönetimine getirerek, dış politikada militarist yönelimin tescillenmesini de sağlamaktadır.

$\mathrm{Bu}$ çalışmanın da dikkat çektiği üzere, İsrail'in Doğu Akdeniz politikasındaki başlıklar, kamuoyuna sunulduğu versiyonlarından oldukça farklı bir minvalde seyretmektedir. Genel hatlarıyla enerji kaynakları ekseninde geliştirilen diplomasi ve bu minvaldeki işbirliği potansiyeli olarak gelişen İsrail'in Doğu Akdeniz politikası, günümüzde geldiği nokta itibariyle oldukça militarist bir görünüm sunmaktadır.

12 İsrail'i "Garnizon Devlet” olarak sınıflandıran çalışmalardan birkaçı için bknz. Jacob Abadi, Israel's Quest for Recognition and Acceptance in Asia: Garrison State Diplomacy (Londra: Frank Cass, 2004), XI-XXV; Dwight J. Simpson, "Israel: A Garrison State," Current History 58, no. 341 (Ocak 1970): 1-6; Rebecca L. Schiff, "Civil-Military Relations Reconsidered: Israel as an "Uncivil" State," Security Studies 1, no. 4 (1992): 636-658. 


\section{3. İsrail Dış Politikasını Tartışmak: Ulusal Güvenliğin Tahakkümü}

İsrail devletinin bir dış politikası var mıdır? Bu soru, uzun bir süredir akademik çevrelerce dile getirilen bir husustur. Bir dış politika yaklaşımından ziyade caydırıcılık eksenli savunma politikasına sahip olduğu sıklıkla ifade edilir. ${ }^{13} \mathrm{Bu}$ açıdan bakıldığında, İsrail özelinde dış politika ile savunma politikası arasında net bir sınır çizebilmek pek mümkün değildir. Diplomatik aktivizminin altında da çoğu zaman ulusal güvenlik kaygıları barındıran devletin motivasyon kodlarını tarihsel bir zeminde anlamlandırabilmek, önemli bir girişim olacaktır.

İsrail dış politikası, neredeyse devletin bağımsızlığını ilan ettiği yıllardan bu yana belirgin birtakım prensipler üzerinden hareket etmektedir. Bunların başında da kendisine uygulanan diplomatik izolasyonun bir biçimde ortadan kaldırılması ya da mümkün mertebe yumuşatılması yatmaktadır. ${ }^{14}$ $\mathrm{Bu}$ yaklaşımın altında da İsrail'in neredeyse istisnai bir ulusal güvenlik politikası olduğunu belirtmek gerekmektedir.

İsrail dış politika tarihinde diplomatik izolasyonu aşabilmek amacıyla çeşitli girişimler olduğu da gözlemlenebilir. Özellikle coğrafyasını çevreleyen Arap devletlerinin şiddetli reddiyesi, İsrail'i söz konusu Arap çemberinden ötelerde işbirliği yapabileceği aktörler aramaya itmiştir. Bu bağlamda, İsrail devletinin kuruluşundan kısa bir süre sonra, 1950'li yıllarda Arap çemberinin hemen dışında kalan Türkiye, İran ve Etiyopya gibi devletlerle ilişkilerini yoğunlaştırmıştır. Hatta bir süre sonra bu ilişki biçimi bir nevi askeri-istihbari bir ortaklığa dönüşmüş ve İsrail kaynaklarında "Çevre Paktı" olarak anılmaya başlanmıştır. ${ }^{15}$ İşte bütün bu diplomatik aktivizmin

13 Baruch Kimmerling'in aktardığı bir anekdotta, dönemin Başbakanı ve Savunma Bakanı David Ben Gurion'un Dışişleri Bakanı Moşe Şaret'e “Savunma Bakanlığı güvenlik politikalarını belirler, Dışişleri Bakanlığı ise bu politikaları anlatmakla görevlidir" dediğini belirtir. İsrail dış politikası olarak anılan alan, geleneksel olarak, daha ziyade ulusal güvenlik/savunma ihtiyaçlarının hakimiyetindeki bir sahayı tarif eder. Detaylı bilgi için bknz. Baruch Kimmerling, "Patterns of Militarism in Israel," European Journal of Sociology 34, no. 2 (1993): 207. Ayrica daha eski tarihli akademik bir metin için şuraya da bakılabilir: Avi Shlaim ve Avner Yaniv, "Domestic Politics and Foreign Policy in Israel,” International Affairs 56, no. 2 (İlkbahar 1980): 242.

14 Efraim Inbar, "Jerusalem's Decreasing Isolation: Israel in the World," Middle East Quarterly (İlkbahar 2013): 27-38.

15 Ofra Bengio, The Turkish-Israeli Relationship: Changing Ties of Middle Eastern Outsiders (New York: Palgrave Macmillan, 2004), 33-71. 
arka planında, devletin bekasını merkeze alan ulusal güvenlik kaygılarıyla bezenmiş bir yönelimin bulunduğu söylenebilir. $\mathrm{Bu}$ yaklaşımın izleri, tarihsel ve fikri olarak, İsrail devletinin bağımsızlığını henüz kazanmadığı dönemlere kadar sürülebilir.

Büyük güçlerin önerdiği ve ana akım Siyonizm'in kabullendiği coğrafi varlığa itirazla şekillenen Revizyonist Siyonizm, Ürdün nehrinin her iki yakasında kurulacak bir İsrail devletini formüle etmekteydi. ${ }^{16}$ Vladimir Ze'ev Jabotinsky de bu akımın önde gelen sözcüsü konumundaydı. Kendisinin formüle ettiği "Demir Duvar" yaklaşımı, İsrail devletinin bağımsızlı̆̆ını kazanması durumunda uygulaması gereken ulusal güvenlik politikasını programlaştırmaktaydı. Bu yaklaşımın temelinde de o tarihler itibariyle muhayyel İsrail'i çevreleyen Arap devletlerine kıyaslamalı olarak üstünlük kurulması hedeflenmekteydi. Böylece Arap devletleri caydırılabilecek ve İsrail'e karşı oluşturabilecekleri potansiyel tehditler daha başından engellenmiş olacaktı. ${ }^{17}$ Bir başka ifadeyle, kökleri itibariyle İsrail dış politikası, aslında bir savunma doktrinine yaslanmaktadır.

Günümüzde dahi İsrail, ulusal güvenlik ve dış politikasının temeline güçlü bir caydırııılığ 1 konumlandırmaktadır. ${ }^{18}$ Bir savunma politikası yaklaşımı olarak açıklanabilecek olan caydırıcılık, İsrail kontekstinde farklı bir konum kazanarak, dış politikanın da temel direği haline gelmiştir. Hatta öyle ki caydırıcılık politikasındaki olası başarısızlıklar, İsrail toplumu nezdinde de ciddi karş1lıklar bulmuştur. Bu bağlamda, Ekim 1973'teki Yom Kippur Savaşı'nı anmak açıklayıcı olabilir.

Sadece altı yıl öncesinde edinilmiş "büyük zafere" karşın Arap ordularının görece ilerleme sağlaması, bu tarihlerde İsrail devletinde ve toplumunda büyük bir şok etkisi yaratmıştır. ${ }^{19}$ Hatta öyle ki bu savaşta İsrail askeri envanterinde bulunan nükleer silahların bir son çare olarak kullanılması

16 Lenni Brenner, The Iron Wall: Zionist Revisionism from Jabotinsky to Shamir (Londra: Zed Books, 1984), 86.

17 Brenner, The Iron Wall, 73-78.

18 Belfer Center Special Report, Deterring Terror: How Israel Confronts the Next Generation of Threats (USA: Belfer Center, Ağustos 2016), 24-25, https://www. belfercenter.org/sites/default/files/legacy/files/IDFDoctrineTranslation.pdf.

19 Emmanuel Navon, “From Kippur to Oslo: Israel's Foreign Policy, 1973-1993," Israel Affairs 10, no. 3 (2004): 9. 
dahi gündeme gelmiştir. ${ }^{20}$ İsrail toplumu açısından "ikinci bir Holokost ihtimali” olarak algılanan Ekim 1973'teki savaş, İsrail siyasetinde de kısa vadede büyük bir dönüşümün tetikleyicisi olmuştur. Devletin bağımsızlığını kazandığı tarihten itibaren iktidarda bulunan İşçi Partisi, Yom Kippur Savaşı'ndaki görece kötü performansına istinaden, 1977 seçimlerinde iktidara layık görülmemiştir. Bu tarihlerde İsrail toplumunda iyice belirginleșen Sefarad-Mizrahi varlığının da yoğun katkısıyla Likud Partisi, iktidarı devralmıştır. ${ }^{21}$ Bu örnekten de anlaşılabileceği üzere İsrail, ulusal güvenliğinde oluşabilecek aksaklıklara karşı aşırı hassas bir tavır takınabilmektedir.

Benzer bir tavır, Oslo Süreci'nde de gözlemlenmiştir. 1980'li yıllaritibariyle İran İslam Devrimi'nin de yoğun etkisiyle yükselen İslamcı hareketler, Birinci İntifada sürecinde Filistin'deki direnişin öncü temsilcileri haline gelmişlerdi. ${ }^{22}$ Filistin Kurtuluş Örgütü (FKÖ) liderliğinin bu tarihlerde Tunus'ta bulunması, İsrail'in elini güçlendirmiş ve FKÖ'yle barış sürecine gidilmiştir. ${ }^{23}$ Böylece Oslo Süreci olarak bilinen ve çeşitli anlaşmalar imzalanarak Filistin'de bağımsız bir devlet kurulmasını hedefleyen bir süreç başlatılmıştır. Filistin toplumu nezdinde görece olumlu bir yank1 uyandırsa da İsrail toplumunun sağ görüşlü kesimlerinde ciddi tepkiler, yine Oslo Süreci'yle birlikte baş göstermiştir.

Oslo Süreci'ni ve imzalanan anlaşmaları "ihanet" olarak niteleyen sağc1 siyasetçiler, muhayyel Filistin devletine verilecek Batı Şeria üzerinden ciddi bir karşı propagandaya başlamıştır. ${ }^{24}$ Batı Şeria'da bulunan Yahudi yerleşimleri ve buradaki Yahudi nüfus, giderek radikalize bir kitle haline gelmiştir. Bu süreç, Başbakan İzak Rabin'in bir miting esnasında vurularak

20 "Dayan Pushed PM Meir to Consider Using Nuclear Weapons in 1973 War," The Times of Israel, 3 Ekim 2013, https://www.timesofisrael.com/dayan-pushed-pm-meirto-consider-using-nuclear-weapons-in-1973/, Son erişim: 29 Ekim 2020.

21 Colin Shindler, The Rise of the Israeli Right: From Odessa to Hebron (New York: Cambridge University Press, 2015), 295-311.

22 Lisa Taraki, "The Islamic Resistance Movement in the Palestinian Uprising," Middle East Report, no. 156 (Ocak-Şubat 1989): 30-2.

23 Avi Shlaim, “The Oslo Accord," Journal of Palestine Studies 23, no. 3 (İlkbahar 1994): 38.

24 Ehud Sprinzak, "Netanyahu's Safety Belt," Foreign Affairs 77, no. 4 (Temmuz-Ağustos 1998): 18. 
öldürülmesine kadar gitmiştir. ${ }^{25}$ Ayrıca sağ partiler ve özellikle de Benjamin Netanyahu liderliğindeki Likud'un köpürtmesiyle, söz konusu karşı söylem uzun yıllar boyunca devam etmiştir. Kaldı ki Rabin'in öldürülmesinden hemen sonra Netanyahu başbakan seçilmiştir. Bu sonucun altında Filistinli İslamcı grupların Oslo Süreci'ne şiddetli muhalefeti olduğu kadar, İsrail toplumunun güvenlikçi yaklaşımının da yattığı belirtilmelidir.

Bir diğer "başarısızlık hikayesi” de Ariel Şaron'a aittir. 2005 yılında dış politikada bir atak geliştirebilmek, uluslararası kamuoyu nezdinde itibar kazanabilmek ve işgalin yarattı̆̆ külfetten kurtulabilmek adına Gazze'den tek taraflı bir çekilme planını uygulamaya koymuştur. Aslında oldukça makul bir hesaplamanın ürünü olan bu dış politika hamlesi, Şaron'un liderliğini yaptığı Likud Partisi'nin siyasal çizgisine tamamıyla tersti. Ayrıca Gazze'de yıllar içerisinde oluşmuş bir yerleşimciler kitlesi de mevcuttu. Bu durum, haliyle Şaron'a yönelik tepkilerin artmasına sebep olmuştur. Siyasette bulunduğu süre zarfında daha ziyade "bir kahraman" olarak referanslanan Şaron ${ }^{26}$, artık bir "vatan haini" damgası yemiştir. ${ }^{27}$ Kısa bir süre sonra da Likud Partisi'nden ayrılarak Kadima Partisi'ni kurmak zorunda kalmıştır.

Gazze'de bulunan Filistinli direniş örgütlerine taviz olarak algılanan bu çekilme, İsrail ulusal güvenliğine halel getirebileceği kaygısıyla olumsuzlanmıştır. Her ne kadar söz konusu çekilme hayata geçirilmiş ve günümüzde de sürdürülüyor olsa da Şaron'un siyasal kariyerini nahoş bir algıyla bitirmesine vesile olmuştur. Kısa bir süre sonra da hastalanarak başbakanlığ devretmek zorunda kalmıştır. ${ }^{28}$

25 "Assasination in Israel: The Overview; Rabin Slain After Peace Rally in Tel Avib; Israeli Gunman Held; Says He Acted Alone," The New York Times, 05 Kasım 1995, https://www.nytimes.com/1995/11/05/world/assassination-israel-overview-rabinslain-after-peace-rally-tel-aviv-israeli.html, Son erişim: 29 Ekim 2020.

26 Ekim 1973'te gerçekleşen Yom Kippur Savaşı'nda başında bulunduğu birlikle birlikte Süveyş Kanalı'nın batı yakasına geçerek Mısır ordularının arkasına sarkması, İsrail'i muhtemel bir yenilgiden kurtarmıştı. Bu tarihten itibaren Şaron'un itibarı da büyük ölçüde artmıştı.

27 Geoffrey Levin, “Ariel Sharon's Legacy of Separation,” The Atlantic, 11 Ocak 2014, https://www.theatlantic.com/international/archive/2014/01/ariel-sharons-legacy-ofseparation/282955/, Son erişim: 29 Ekim 2020.

28 "A Mild Stroke Sends Sharon to the Hospital," The New York Times, 19 Aralık 2005, https://www.nytimes.com/2005/12/19/world/middleeast/a-mild-stroke-sends-sharonto-the-hospital.html, Son erişim: 29 Ekim 2020. 
2020 yılında açıklanan "Yüzyılın Anlaşması" da benzer bir reaksiyonla karşılaşmıştır. Bu anlaşma metnini Amerika Başkanı Donald Trump'ın hem danışmanı hem de damadı sıfatıyla hazırlayan Jared Kushner'in İsrail yanlısı bir tutum takındığ ${ }_{1}$ ve bunu da anlaşmanın hükümlerine yansıttığ sıklıkla ifade edilse de nihai kertede Başbakan Netanyahu, özellikle de Batı Şeria ile ilgili hükümleri önemsemiştir. Hem teolojik hem de savunma kapasitesi bağlamında anlam yüklenen Batı Şeria, anlaşma hükümleri uyarınca İsrail devletinin ilhak ihtimaliyle karşılaşmıştır. Netanyahu'nun temsil ettiği revizyonist Siyonist çizgi açısından oldukça tutarlı bir talep olarak Batı Şeria'nın ilhakı, İsrail kamuoyundan kaynaklanabilecek aşırıcı tepkileri de önleyebilecek bir hamle olarak görülmüştür.

Bir süre sonra Birleşik Arap Emirlikleri (BAE) ile imzalanan İbrahim Anlaşması, İsrail'in Batı Şeria'yı ilhakını durdurmuş ve BAE yetkilileri de kendileri açısından söz konusu anlaşmayı, Batı Şeria'nın ilhakını engelleyebilmek üzerinden meşrulaştırmaya çalışmıştır. ${ }^{29}$ Fakat Netanyahu, olası tepkilerin şiddetinden de çekindiği için olsa gerek, Batı Şeria'nın ilhakının durdurulmadığını ya da iptal edilmediğini, aksine sadece ertelendiğini duyurmak gerekliliğini hissetmiştir. ${ }^{30} \mathrm{Bu}$ durum da kuşkusuz Netanyahu'nun hem partisinin tabanından hem de genel kamuoyundan alabileceği tepkileri hesaba kattığını göstermektedir.

İsrail dış politikası, yukarıda anlatılanların ışı̆̆ında değerlendirildiğinde, sivil bir içerik ve tercihler silsilesi olmaktan ziyade, askeri birtakım ihtimaller ve gereklilikler üzerine inşa edilmiştir. Ayrıca yine net bir biçimde anlaşılabileceği üzere, İsrail kamuoyu da ulusal güvenlik eksenli dış politikanın sıkı takipçisi görünümündedir. Bir başka ifadeyle, İsrail kamuoyu güvenlik diline oldukça teşne bir nitelik sunmaktadır. Bu açıdan bakıldığında, güvenlikleştirici aktörlerin görece kolay bir söylemsel imkana sahip oldukları iddia edilebilir. Lakin güvenlik uygulamalarındaki olası aksaklıklar, kamuoyunun sıkı takibi neticesinde, ilgili siyasi aktörlerin k1sa vadede siyaset sahnesinden silinmelerine sebep olabilmektedir.

29 Oraib Al Rantawi, “The UAE Lie of 'Stopping' Israel's West Bank Annexation," Yedioth Ahronot, 12 Eylül 2020, https://www.ynetnews.com/article/SyVh9A74D, Son erişim: 29 Ekim 2020.

30 "Netanyahu Says Israel's Annexation Plan of Occupied West Bank Suspended 'for Time Being,", Daily Sabah, 17 Ağustos 2020, https:/www.dailysabah.com/world/ mid-east/netanyahu-says-israels-annexation-plan-of-occupied-west-bank-suspendedfor-time-being, Son erişim: 29 Ekim 2020. 
Günümüzde Doğu Akdeniz'deki gelişmelerde de İsrail dış politikasının benzer pozisyonlar aldığ 1 gözlemlenebilir. Bu bağlamda, enerji alanında işbirliği ve dolayısıyla enerji diplomasisi olarak öne çıkan başlıklar ve ülkeler, büyük bir süratle askeri terminolojinin sahasına girmekte ve bu minval üzere güvenlikleştirilmektedir. İsrail'in hem Yunanistan'la hem de GKRY ile geliştirdiği ilişkiler, bu tanımlamaya neredeyse birebir uymaktadır.

\section{4. İsrail'in Doğu Akdeniz Politikasında Militarizm}

İsrail'in Doğu Akdeniz politikasına genel hatlarıla bakıldığında, dış politikasındaki ulusal güvenlik eksenli değerlendirmelerin ve uygulamaların bu bölgede de fazlasıyla hayata geçirildiği rahatlıkla tespit edilebilir. Bu bağlamda, Türkiye ile 1990'lı yılların ikinci yarısında hayata geçirdiği işbirliğinin ve 2010'lu yıllarda da Yunanistan-GKRY ikilisiyle yakınlaşmasının özünü askeri ilişkiler oluşturmaktadır. Bir diğer ifadeyle militarizm, İsrail'in Doğu Akdeniz politikasının hakim rengini temsil etmektedir.

Yukarıda da anıldığı üzere İsrail'in Yunanistan-GKRY aksıyla geliştirdiği ilişkileri, ekseriyetle 2009 yılında keşfedilen doğalgaz yataklarına dayanmaktadır. GKRY'nin sözde münhasır ekonomik bölgesine (MEB) tekabül eden Afrodit rezervi ve İsrail MEB'inin sınırları içerisinde kalan Leviathan ve Tamar doğalgaz yatakları, ikili ve üçlü ilişkilerin hızlı bir biçimde gelişmesinin temel tetikleyicileri olmuştur. ${ }^{31}$

İsrail-Türkiye ilişkilerinin kötüleşmeye başlaması, Doğu Akdeniz bölgesi açısından 2009 sonrası yeni dönemin işaret fişeği fonksiyonunu üstlenmiştir. Bu bağlamda, 29 Ocak 2009 tarihinde İsviçre'nin Davos kasabasında Dünya Ekonomik Forumu kapsamında düzenlenen “Gazze: Ortadoğu'da Barış Modeli” başlıklı panelde konuşmacı olan Başbakan Erdoğan, İsrail Cumhurbaşkanı Şimon Peres'in şahsında İsrail politikalarına yönelik olarak ağır eleştirilerde bulunmuş ve paneli terk etmiştir. ${ }^{32}$ Bu gelişmeyle

31 Tuğçe Ersoy, "Emerging Alliances, Deteriorating Relations: Turkey, Israel and Greece in the Eastern Mediterranean," içinde Contemporary Israeli-Turkish Relations in Comparative Perspective, ed. Ayşegül Sever ve Orna Almog (Cham: Palgrave Macmillan, 2019), 101.

32 “Benim İçin Davos Bitti," Hürriyet, 30 Ocak 2009, https://www.hurriyet.com.tr/ dunya/benim-icin-davos-bitti-10886978, Son erişim: 29 Ekim 2020. 
birlikte Türkiye-İsrail ilişkileri de düşüşe geçmiş ve bir krizler sarmalının içerisine girmiştir. Doğu Akdeniz'de stratejik bir işbirliğini temsil eden İsrail-Türkiye ilişkilerinin çökmesi, İsrail'in bölgenin diğer devletlerine yönelmesinin de önünü açmıştır. Bu bağlamda, Türkiye gibi bir NATO üyesi ve ayrıca AB üyesi olan Yunanistan'la ilişkilerini yoğunlaştırmıştır.

Davos'ta yaşanan ve kamuoyunca "One Minute!” krizi olarak bilinen vakıa, aslında Türkiye-İsrail ilişkilerinin politik sektöründe büyük bir kırılma yaratmıştır. Bu tarihten sonra askeri sektördeki ilişkiler bir biçimde devam etse de 31 Mayıs 2010 gecesi yaşanan Mavi Marmara baskınıyla birlikte nihayete ermiştir. Bu bağlamda, Mavi Marmara baskını ve İsrail'in uluslararası hukuka aykırı bir biçimde burada ölümlerine sebep olduğu dokuz Türk vatandaşı, Türkiye'nin İsrail'le olan askeri işbirliğine de nokta koymasını beraberinde getirmiştir. Bu tarih, İsrail'in özellikle Yunanistan'la askeri ilişkilerini geliştirmeye yoğunlaştığı bir milat olarak düşünülebilir. ${ }^{33}$

Hatta Türkiye-İsrail ilişkileri açısından Davos'ta yaşanan politik kırılma ve bir krizler sarmalı olarak bu durumun yarattığı güç boşluğu, İsrail tarafından ivedilikle doldurulmaya çalışılmıştır. $\mathrm{Bu}$ bağlamda İsrail Başbakanı Netanyahu, Şubat 2010'da Moskova' daki Puşkin Cafe'de Yunan mevkidaş1 Papandreu ile görüşmüş ve bu görüşmede Yunan mevkidaşını İsrail'e davet etmiştir. Aynı senenin Temmuz ayında İsrail'e giden Başbakan Papandreu'nun ziyaretine karş11ı bir ay kadar sonra, Ağustos 2010 'da da Başbakan Netanyahu Yunanistan'a bir ziyarette bulunmuştur. ${ }^{34}$ İsrail ve Yunanistan arasında oldukça hızlı bir biçimde cereyan eden bu yakınlaşma, İsrail'in Doğu Akdeniz'de ile yani Türkiye ile uzun yıllara dayanan askeri işbirliğini bir an önce ikame etmeye çabalamasıyla anlaşılabilir. Henüz Türkiye-İsrail ilişkileri bir biçimde tamir edilebilir bir pozisyondayken, Başbakan Netanyahu'nun izlediği siyasetten Türkiye'nin gözden çıkarıldığı anlaşılmaktadır. Benzer bir içerik inşa edilerek, bu sefer de Yunanistan'la askeri bir işbirliği için ortak zemin yaratılmaya çalışılmaktadır. Bir diğer ifadeyle İsrail, bölge siyasetinde militarist bir pozisyonu korumakta ve konsolide etmektedir.

12 Aralı 2010 tarihli The Jerusalem Post gazetesinin haberine göre,

33 Ersoy, "Emerging Alliances," 132.

34 "Netanyahu's Big Fat Greek Wedding," Haaretz, 1 Temmuz 2011, https://www. haaretz.com/1.5024702, Son erişim: 18 Ekim 2020. 
İsrail savunma endüstrisinden ve Savunma Bakanlığı'ndan yetkililer, Yunan Hava Kuvvetleri'ne milyonlarca dolarlık silah satışı için temaslarda bulunmuşlardır. ${ }^{35} \mathrm{Bu}$ açıdan bakıldığında, Doğu Akdeniz'deki güç dengelerini de dönüştürebilecek olan söz konusu silah satış pazarlıkları, Türkiye'nin gözden çıkarılmasıyla alakalı olduğu kadar, İsrail' in militaristik yaklaşımıyla da birebir örtüşmektedir. Yunanistan'la ilişkilerini ekseriyetle enerji diplomasisi alanından meşrulaştırma çabası içerisinde olan İsrail, aksine ulusal güvenliğin sahasına giren eylemlerle biçim verdiği bir ortaklığın arifesindedir.

Aynı tarihlerde buna paralel bir diğer gelişme de İsrail-GKRY arasında ortaya çıkmıştır. Bu bağlamda İsrail ve GKRY, deniz yetki sahalarını ve münhasır ekonomik bölgelerini belirleyen bir anlaşmaya imza koymuşlardır. ${ }^{36}$ Böylece iki ülke arasında bir işbirliği alanı tesis edilmekle birlikte, yakınlaşmalarının lokomotifini daha ziyade askeri ortaklıklar oluşturmuştur. Hatta söz konusu anlaşma akabinde, tarihte ilk defa bir GKRY Cumhurbaşkanı İsrail'e resmi bir ziyarette bulunmuş ve iki ülke savunma bakanları, kısa bir süre içerisinde karşılıklı temaslarını yoğunlaştırarak, askeri işbirliklerinin zeminini hazırlamışlardır. ${ }^{37}$

$\mathrm{Bu}$ tarihlere de tekabül etmesi açısından, İsrail ve Yunanistan arasındaki ilişkiler özellikle askeri alanda ivme yakalamış ve iki ülke ilişkileri ortak askeri tatbikat düzenlemeye varan bir güzergah takip etmiştir. ${ }^{38} \mathrm{Bu}$ bağlamda, henüz Doğu Akdeniz'deki enerji yataklarına dair herhangi bir ortak gelecek projeksiyonu öngörülmezken, Yunanistan'ın hava sahasında

35 "Israeli Defense Industries in Talks with Greek Army," The Jerusalem Post, 12 Aralık 2010, https://www.jpost.com/defense/israeli-defense-industries-in-talks-with-greekarmy, Son erişim: 18 Ekim 2020.

36 "Cyprus and Israel Sign Deal Demarcating Sea Borders," Haaretz, 17 Aral1k 2010, https://www.haaretz.com/1.5094734, Son erişim: 28 Ekim 2020.

37 Marinos Papaioakeim, "The Rise of the Cyprus' Defence Diplomacy in its Neighbourhood," The Cyprus Review 30, no. 1 (İlkbahar 2018): 99-102.

38 Aslında iki ülke arasında düzenlenen ilk tatbikat, 28 Mayıs-12 Haziran 2008 tarihleri arasındaki Glorius Spartan'dır. Lakin bu hava tatbikatı ekseriyetle İran'1 hedef almıştır. Bknz. "U.S. Says Israeli Exercise Seemed Directed at Iran," The New York Times, 20 Haziran 2008, https://www.nytimes.com/2008/06/20/washington/20iran.html, Son erişim: 18 Ekim 2020. Bu bağlamda, dış politikada İsrail militarizmine yönelik bir temel oluştursa da Doğu Akdeniz dengeleri açısından değerlendirilemeyecek bir gelişmedir. Tziampiris, İran'ı hedef aldığı belirtilen tatbikat için seçilen ismin dahi oldukça manidar olduğunu belirtir. Detaylı bilgi için bknz. Aristotle Tziampiris, The Emergence of Israeli-Greek Cooperation (Londra: Springer, 2015), 77-78. 
ortak bir askeri tatbikat gerçekleştirmişlerdir. Ekim 2010'da gerçekleşen tatbikat kapsamında İsrail, Apache ve Black Hawk helikopterleriyle katılım göstermiş ve buna mukabil Yunan hava gücü de helikopterler ve jetlerle eşlik etmiştir. ${ }^{39}$ Özellikle hava sahasının kısıtlı1ı̆̆ sebebiyle İsrail, hava gücünün eğitimini Türkiye ile ilişkileri kötüleşmeden evvel Türk hava sahasını kullanarak yaptığından, Yunan hava sahasını Türkiye'nin ikamesi olarak görmüş ve bu ülkeyle ilişkilerine bu minvalde özel bir önem atfetmiştir. ${ }^{40}$

Ayrıca 2011 y1lından itibaren İsrail, Yunanistan ve ABD'nin katıldığ Noble Dina isimli deniz tatbikatı da düzenlemektedir. Bu bağlamda anmak gerekir ki söz konusu tatbikatın başlangıç tarihi, Türkiye-İsrailABD katılımıla düzenlenen Reliant Mermaid isimli deniz tatbikatından Türkiye'nin çekildiği tarihlerle örtüşmektedir. Yukarıda da anıldığı üzere, İsrail donanmasının Mavi Marmara gemisine düzenlediği baskın neticesinde Türk vatandaşlarının öldürülmesi, Türkiye'nin ortaklarından olduğu söz konusu tatbikattan çekilmesine yol açmıştır. Böylece oluşan güç boşluğundan Yunanistan faydalanarak, İsrail-ABD ikilisinin bölgesel ortağı hüviyetine kavuşmaya çalışmıştır. Kısacası Noble Dina isimli deniz tatbikat1, 1998-2009 arasında yapılan Reliant Mermaid' in ikamesidir. ${ }^{41}$

Kuşkusuz yukarıda anlatılanlar, İsrail'in Doğu Akdeniz politikasındaki ulusal güvenlik vurgusuna yönelik oldukça güçlü verilerdir. Henüz enerji diplomasisi sahasında herhangi bir ilerleme sağlanmamışken İsrail, Yunanistan'la ortak askeri tatbikatlar düzenlemeye başlamıştır. $\mathrm{Bu}$ bağlamda, Doğu Akdeniz bölgesindeki güç dengeleri de dönüşmüş ve İsrail, bölgesel ittifak yapılanmasını, Yunanistan'la Türkiye'yi ikame ederek şekillendirmiştir.

2011 yılının son günlerine kadar yapılan ortak askeri tatbikatlar ayrıca anlamlıdır. Hatta birtakım iddialara göre, 2010-2012 yılları arasında İsrail ve Yunanistan'ın ortaklaşa düzenledikleri askeri tatbikatların sayısı

39 "Israel Woos Greece After Rift With Turkey," BBC, 16 Ekim 2010, https://www.bbc. com/news/world-middle-east-11556442, Son erişim: 17 Ekim 2020.

40 "Israeli Military Offsets Turkey's Loss with Greece, Romania," Asbarez, 29 Eylül 2010, http://asbarez.com/85907/israeli-military-offsets-turkeys-loss-with-greece-romania/, Son erişim: 26 Ekim 2020.

${ }^{41}$ Jean-Loop Samaan, The East Mediterranean Triangle at Crossroads (US: Strategic Studies Institute and U.S. Army War College Press, 2016), 1-2. 
en az 13 'tür. ${ }^{42}$ Genel hatlarıla enerji diplomasisiyle açıklanan İsrail'in Doğu Akdeniz politikası, ulusal güvenliği baskın bir biçimde vurgulayan askeri güvenlik girişimlerinin yansımaları olarak görülebilir. Doğu Akdeniz'de keşfedilen ve fakat resmi raporlarla ispatlanmamış olan enerji yataklarının potansiyelinin Aralık 2011'de açıklanması, bu tarihe kadar yapılan ortak askeri tatbikatların politik zeminine dair genel geçer iddiaları yanlışlamaktadır. ${ }^{43}$ Bir diğer ifadeyle İsrail, Doğu Akdeniz politikasında Türkiye'yi dengeleyebilmek adına, enerji diplomasisini öne çıkartarak, askeri girişimlerini sümenaltı etmeye çalışmıştır.

Ortak askeri tatbikatlar bir yandan hiz kesmeden devam ederken, İsrail ile GKRY arasında imzalanan anlaşmalar yine İsrail'in militarize Doğu Akdeniz politikasına güçlü veriler sağlamıştır. İsrail menşeli Globes sitesinin haberine göre, savunma işbirliği ve istihbarat alanında yapıldığ ifade edilen anlaşmalar, GKRY Savunma Bakanı Demetris Eliades'in İsrail'e yaptığı ziyaret esnasında hayata geçirilmiştir. ${ }^{44}$ Bu noktada önemli olan bir diğer husus ise İsrail' in Türkiye politikasında da belirgin bir değişim gözlenmesidir. Bu bağlamda İsrail, Türkiye'nin Kıbrıs adasına yönelik hassasiyetlerini biliyor olmasına rağmen, Türkiye-İsrail ilişkilerinin tamiri açısından ihtimallerin bulunduğu Ocak 2012 gibi oldukça erken bir tarihte, GKRY ile savunma ve istihbarat alanında anlaşma imzalayabilmiştir.

İsrail ile GKRY arasındaki ilişkilerin kapsamı, salt iki ülke arasındaki diplomatik gelişmelerle sınırlı olmayıp, ABD'deki lobicilik faaliyetlerini de içermektedir. ${ }^{45}$ Helen Amerikan Liderlik Konseyi (HALC-Hellenic American Leadership Council) ile Amerikan Yahudi Topluluğu (AJCAmerican Jewish Community) arasındaki ilişkiler, özellikle 2013 yılı

42 George N. Tzogopoulos, "The Future of Greek-Israeli Relations," BESA Center Perspective Paper, no. 788, 8 Nisan 2018, https://besacenter.org/perspectives-papers/ greece-israel-relations/, Son erişim: 22 Ekim 2020.

43 George Stavris, "The New Energy Triangle of Cyprus-Greece-Israel: Casting a Net for Turkey?," Turkish Policy Quarterly 11, no. 2 (Yaz 2012): 90.

44 "Israel, Cyprus Sign Defence Agreements - Reports," Globes, 10 Ocak 2012, https:// en.globes.co.il/en/article-1000714277, Son erişim: 22 Ekim 2020.

45 AJC'nin Mavi Marmara Baskını sonrasında GKRY'yi ziyaret ettiği ve burada GKRY Lideri Hristofyas ile görüştüğü de bilinmektedir. Bu görüşmede AJC heyeti, Kıbrıs için "neler yapabileceklerini" istişare etmişlerdir. Amerikan yönetimini baskılama potansiyeliyle bilinen Yahudi lobisinin bu önemli kuruluşu, bu ifadelerle kuşkusuz ki GKRY'ye Amerikan yönetimi nezdinde politik destek vaadinde bulunmaktadır. Bknz. Stavris, "The New Energy," 92. 
itibariyle farklı bir safhaya girmiştir. Bu bağlamda, Amerikan Kongresi'nde etkinlik kazanabilme ve güçlerini ortak çıkarlar doğrultusunda organize edebilmek adına, Senatör Gus Bilirakis ve Senatör Ted Deutch tarafindan Kongre Helen İsrail İttifakı (Congressional Hellenic Israel Alliance) kurulmuştur. ${ }^{46} \mathrm{Bu}$ hamleyle birlikte Yahudi lobisi ve Rum lobisi koordinasyon halinde, İsrail ve GKRY arasındaki ilişkileri güçlendirmek, Türkiye'ye yönelik silah satışlarına sınırlama getirebilmek ve GKRY'ye yönelik uygulanan silah ambargosunu kaldırabilmek ekseninde lobi faaliyetleri yürütmüşlerdir. ${ }^{47}$

Yukarıda anlatılanlar doğrultusunda, İsrail ve GKRY'nin dolaylı olarak ortak askeri hedefler belirleyerek, Türkiye aleyhinde çalışmalar yaptığ anlaşılabilmektedir. Daha ziyade güvenlik işbirliğinin yansımaları olarak görülebilecek söz konusu gelişmeler, 2013 yılı itibariyle Türkiye'nin dengelenmesi çabalarının bir sonucu olarak da okunabilir. ${ }^{48}$

Hatta söz konusu lobilerin işbirliği göreceli olarak kurumsallaşmış ve 2018 y1lında Lefkoşa' da düzenlenen kutlama organizasyonuyla taçlandırılmıştır. GKRY'deki Yunan Büyükelçiliğinde Kathimerini gazetesinin editörü Tom Ellis'in moderatörlüğünde yapılan kutlama toplantısında konuşan Kongre Helen İsrail İttifakı Direktörü Endy Zemenides, ilişkilerin seyrini de özetleyen ifadeler kullanmıştır. İsrail'in Yunanistan-GKRY ikilisiyle geliştirdiği güvenlik ilişkilerinin teyidi olarak da görülebilecek olan açıklamalarında Zemenides, enerji diplomasisiyle başlayan sürecin güvenlik işbirliğine doğru hızla evrildiğini ifade etmiştir. ${ }^{49}$

6 Kasım 2013 tarihli The Times of Israel haberine göre İsrail, tarihinin

46 Gus M. Bilirakis ve Ted Deutch, "Hellenic-Israeli Partnership Strengthens Democracy," The Washington Times, 13 Şubat 2013, https://www.washingtontimes.com/news/2013/ feb/13/bilirakis-and-deutch-hellenic-israeli-partnership-/, Son erişim: 17 Ekim 2020.

47 "HALC, AJC Join Forces in Effort to Bolster Cyprus Security, Halt Sale of F-35 Jets to Turkey," Kathimerini, 7 Mayis 2018, https://www.ekathimerini.com/228354/article/ ekathimerini/comment/halc-ajc-join-forces-in-effort-to-bolster-cyprus-security-haltsale-of-f-35-jets-to-turkey, Son erişim: 17 Ekim 2020.

48 Arye Mekel, "Birth of A Geopolitical Bloc: The Israel-Greece-Cyprus Axis," Haaretz, 31 Ocak 2016, https://www.haaretz.com/israel-news/.premium-birth-of-ageopolitical-bloc-the-israel-greece-cyprus-axis-1.5397833, Son erişim: 26 Ekim 2020.

49 "AJC, HALC Mark Fifth Anniversary of Congressional Greece-Israel Alliance," Kathimerini, 10 Mayıs 2018, https://www.ekathimerini.com/228513/article/ekathimerini/ community/ajc-halc-mark-fifth-anniversary-of-congressional-greece-israel-alliance, Son erişim: 18 Ekim 2020. 
en büyük hava gücü tatbikatını yine Yunanistan'ın ortaklığında, $A B D$ ve İtalya'nın da katılımıyla gerçekleştirmiştir. Bu sefer İsrail hava sahasının kullanıldığı tatbikat, İsrail tarihinin en geniş kapsamlı hava tatbikatı olması açısından da oldukça açıklayıcıdır. Eilat şehrinin yakınlarında bulunan Uvda üssünü merkez alan tatbikat sebebiyle, İsrail hava sahasının neredeyse yarısına tekabül eden güney koridoru araç trafiğine kapatılmıştır. Amerikan tatbikatlarına referansla Blue Flag olarak isimlendirilen tatbikatın ekseriyetle bir önceki ay Cenevre'de başlatılan İran nükleer görüşmelerine cevap niteliğinde olduğu haberlere yansımıştır. ${ }^{50}$ Lakin Yunanistan'ın bu tatbikattaki konumu, İran'a yaklaşımı noktasında oldukça tartışmalıdır. Bu bağlamda Yunanistan'ın tatbikattaki konumu, daha ziyade Türkiye'nin yokluğuyla anlamlandırılabilir. İsrail için Doğu Akdeniz'de yeni bir askeri ortak olarak beliren Yunanistan, her ne kadar İran politikaları noktasında ayrışsa da İsrail'le ortak askeri tatbikatlar düzenleme yoluyla, Türkiye'ye mesaj verme kaygısı taşımaktadır. Ayrıca İsrail açısından Doğu Akdeniz politikasındaki militarizasyonun da bir başka örneği olarak telakki edilebilir. Tatbikatın ortaklarının NATO ülkelerinden oluşması da ayrıca kayda değerdir. Denilebilir ki İsrail, Doğu Akdeniz'deki askeri girişimlerini NATO k1lıfıyla örtmeye çalışmaktadır.

Üç ülkenin yakınlaşmasının bir diğer kırılma noktası ise 2014 yılıdır. 2014 yılında Türkiye' nin Kıbrıs adasının güneyinde başlattığı sismik araştırmalar, GKRY'nin sözde MEB'ine tekabül etmesi sebebiyle hem GKRY'nin hem de Yunanistan'ın Türkiye'den algıladığı tehdidi arttırmıştır. Bu gelişme de Yunanistan ve GKRY'nin İsrail'le yakınlaşması için oldukça güçlü bir gerekçe oluşturmuştur. ${ }^{51}$

2014 yılının kritik bir yıl olarak algılanmasının temelinde ise İsrail'in GKRY ile ortak askeri tatbikatlar faslını artık bir anlaşmayla taçlandırmış olmasında yatmaktadır. İki ülke arasında yapılan anlaşma neticesinde, İsrail-GKRY ikilisinin ortak askeri tatbikatlarını programlı ve sistematik bir biçimde devam ettirme arzusunda oldukları anlaşılmaktadır. ${ }^{52}$

50 "Israel Preps for Massive Air Drill with US, Greece, Italy," The Times of Israel, 6 Kasim 2013, https://www.timesofisrael.com/israel-to-conduct-massive-air-drill-withus-greece-italy/, Son erişim: 22 Ekim 2020.

51 Zenonas Tziarras, “Israel-Cyprus-Greece: A ‘Comfortable'Quasi-Alliance,” Mediterranean Politics 21, no. 3 (2016): 415.

52 A. Murat Ağdemir, "Relations Between Israel and the South Cyprus Greek Administration: A New Alignment in the Eastern Mediterranean?," Perceptions XXI, no. 2 (Yaz 2016): 110. 
Bu bağlamda, 11 Şubat 2014 tarihinde ilk Onisilos-Gideon tatbikatı gerçekleştirilmiş ve iki ülke arasındaki askeri işbirliği pekiştirilmiştir. ${ }^{53}$ Sonrasında aynı tatbikatın ikinci ayağı olarak, 21 Ekim 2014'te gerçekleştirilen Onisilos-Gideon tatbikatı da anılması gereken ortak askeri girişimlerdendir. İsrail ile GKRY'nin ortaklaşa düzenledikleri askeri tatbikat, GKRY'nin hava sahasında gerçekleştirilmiştir. ${ }^{54}$ İki ülke arasında yürürlüğe giren savunma işbirliği anlaşması, söz konusu tatbikatların da yasal zeminini oluşturmaktadır. Böylece düzenli olarak ortak askeri tatbikatlar düzenlenebilmektedir.

İsrail'in Yunanistan-GKRY ile geliştirdiği askeri ilişkileri, Ortadoğu özelinde yaşadığ takım işlevsel olanaklar sunmuştur. Bu açıdan bakıldığında, Rusya'nın Suriye'de konuşlandırdığı S-400 hava savunma sistemlerinin İsrail Hava Kuvvetleri'ni sinırlandırıc1 etkisi, Girit'te bulunan S-300 sistemleri üzerinden anlaşılmaya çalışılmıştır. 2015 yılında Girit’te konuşlu bulunan S-300 hava savunma sistemleri, İsrail Hava Kuvvetleri tarafindan test edilmiş ve bu bağlamda, İsrail jetleri S-300 sistemlerinin kilitlenme, radar izleme ve sistemi körleştirme ihtimallerine dair veri toplamaya çalışmıştı. ${ }^{55}$

29 Ekim 2015 tarihli Defence News'in haberine göre İsrail, 2013'teki Blue Flag tatbikatının devamı niteliğinde iki hafta süren bir askeri tatbikat düzenleyerek, Doğu Akdeniz'deki militarist görünümünü güçlendirmeye devam etmiştir. $\mathrm{Bu}$ tatbikat kapsamında önemli bir husus ise tatbikatın aslında NATO üyeleriyle gerçekleştirilmiş olmasıdır. ${ }^{56} \mathrm{ABD}$, Polonya ve Yunanistan'ın katıldıkları tatbikat, hem İsrail'in NATO ülkeleriyle dolaylı bir ilişki biçimi geliştirmesine işaret etmekte hem de Yunanistan'la geliştirdiği askeri ilişkileri NATO kılıfıyla perdelemesine yardımcı olmaktadir.

53 Papaioakeim, “The Rise,” 100.

54 "Cyprus and Israel Complete Onisilos-Gideon Exercise," Gold News, 22 Ekim 2014, http://www.goldnews.com.cy/en/economy/cyprus-and-israel-complete-onisilosgideon-exercise, Son erişim: 28 Ekim 2020.

55 "Israel Trained Against Russian-made Air Defense System in Greece: Sources," Reuters, 4 Aralık 2015, https://www.reuters.com/article/us-mideast-crisis-israelgreece-idUSKBN0TN10G20151204, Son erişim: 26 Ekim 2020.

56 "Israel Concludes Multinational Blue Flag Drill," Defence News, 29 Ekim 2015, https:// www.defensenews.com/training-sim/2015/10/29/israel-concludes-multinational-blueflag-drill/, Son erişim: 22 Ekim 2020. 
2017 yılında da söz konusu ilişkiler daha ziyade askeri bir zeminde yürümeye devam etmiştir. Bu bağlamda, Mart ayında gerçekleştirilen Onisilos-Gideon tatbikatı da oldukça mühimdir. Lefkoşa'nın hava sahasında gerçekleştirilen tatbikata İsrail Hava Kuvvetleri'nden çok sayıda jet katılmıştır. ${ }^{57}$ GKRY'nin de askerleri ve zırhlı araçlarıyla katıldığ tatbikat, İsrail'in Kıbrıs adasında tatbikat yapabiliyor olması açısından ayrıca anlamlıdır.

Mart 2017'de yapılan Iniohos tatbikatı da NATO katılımının yoğun olduğu bir gelişme olarak not edilmelidir. Bu bağlamda; İsrail, Yunanistan, İtalya, $A B D$ ve Birleşik Arap Emirlikleri söz konusu tatbikatın katılımcıları olarak bulunmuşlardır. ${ }^{58} \mathrm{Bu}$ noktada dikkat çeken husus, BAE'nin bir biçimde NATO üyelerinin de iştirak ettiği tatbikatın parçası olması ve Doğu Akdeniz'de görünürlük kazanması olarak not edilebilir.

2017 yılının ilerleyen aylarında iki ülke yeniden bir askeri tatbikat yapmışlardır. 10 Haziran 2017 tarihli The Jerusalem Post'un haberine göre, önceki tatbikatlara kıyasla, iki ülke arasındaki en geniş katılımlı kara tatbikatı gerçekleştirilmiştir. Yaklaşı olarak 400 İsrail komandosunun GKRY'ye gittiği, İsrail Hava Kuvvetleri'ne bağlı çok sayıda helikopter ve jetin de tatbikata katıldığ

Haaretz gazetesinin Kathimerini gazetesinin haberine dayandırdığ 19 Mart 2019 tarihli haberi, Girit'e konuşlandırılacak yeni bir radar sisteminden bahsetmektedir. Buna göre, İsrail-Yunanistan-GKRY üçlüsünün askeri işbirliklerinin devamı niteliğinde bir çalışma düşünülmektedir. Girit adasına konuşlandırılacak İsrail yapımı bir radar sistemiyle, özellikle Türkiye'nin Ege Denizi ve Doğu Akdeniz havzasındaki hareketleri an be an takip edilebilecektir. ${ }^{60}$ Tamamıla askeri bir minvalde kurgulanan radar

57 "Armed Forces of Cyprus and Israel Conduct the Exercise 'Onesilos-Gedeon'," Parikiaki, 20 Mart 2017, http://www.parikiaki.com/2017/03/armed-forces-of-cyprusand-israel-conduct-the-exercise-onesilos-gedeon/, Son erişim: 22 Ekim 2020.

58 "Iniochos 2017 Exercise," Hellenic Air Force, Mart 2017, https:/www.haf.gr/ en/2017/03/iniohos-2017-exercise/, Son erişim: 26 Ekim 2020.

59 "Israeli Commandos Head to Cyprus for Largest Land-Based Drill," The Jerusalem Post, 10 Haziran 2017, https://www.jpost.com/israel-news/israeli-commandos-headto-cyprus-for-largest-land-based-drill-496421, Son erişim: 22 Ekim 2020.

60 "Israel, Greece Construct New Radar System on Crete, Report Says," Haaretz, 19 Mart 2019, https:/www.haaretz.com/israel-news/israel-greece-constructing-new-radar-in-cretereport-says-1.7039210, Son erişim: 26 Ekim 2020. 
projesi, Doğu Akdeniz'deki dengelerin dönüşümüne, Türkiye'ye karş1 mevzilenmeye ve yine İsrail'in militarist perspektifine işaret etmektedir.

Iniohos 2019 ismiyle Yunanistan'da yapılan ortak askeri tatbikat da Doğu Akdeniz'deki askeri tansiyonun yüksekliğine işaret eden bir başka gelişme olarak görülebilir. Bu tatbikat kapsamında Yunanistan; ABD, İtalya, Birleşik Arap Emirlikleri (BAE) ve İsrail'e ev sahipliği yapmıştır. Atina'nın hava sahasında yürütülen hava tatbikatına çeşitli nitelikteki çok sayıda jet katılmıştır. ${ }^{61}$ İsrail açısından bakıldığında, yine bir NATO tatbikatı profiline sahip olsa da BAE'nin varlığı, söz konusu tatbikatın farklı amaçları olduğu yönünde şüpheler uyandırmaktadır. Bu bağlamda, Türkiye'nin bölgesel düzeyde yaşadığı tehdit algılamalarının sebeplerinden birisi olarak BAE'ye Doğu Akdeniz'de alan açılması, kuşkusuz ki İsrailYunanistan ikilisinin zemin hazırladığı bir gelişmedir.

3-14 Kasım 2019'da bir diğer Blue Flag tatbikatı gerçekleştirilmiş ve İsrail, Yunanistan, Almanya, İtalya ve ABD katılım göstermişlerdir. ${ }^{62}$ İsrail'in düzenlediği bu tatbikatta ilk defa F-35 jetleri de boy göstermiştir. Uvda üssünde gerçekleştirilen hava tatbikatı bağlamında belirtilmesi gereken husus, İsrail ile Yunanistan'ın bölgesel düzeydeki askeri işbirliklerini uluslararası bir çerçeve içerisinde kurumsallaştırmış olmalarıdır. Yine NATO üyesi katılımcılarla belirginleşen tatbikat, İsrail'in bölgesel düzeydeki militarist varlığını da tescil eden bir diğer gelişme olarak kaydedilebilir.

\section{1. Üçlï Zirvelerin Analizi}

İsrail'in Doğu Akdeniz politikası kapsamında Yunanistan ve GKRY ile geliştirdiği ilişkileri, bir süre sonra kurumsallaşarak, üçlü zirvelerin yapıldığı bir bölgesel işbirliği platformu olarak şekillenmiştir. Bu aşamada, üçlü zirvelerin ele aldığ 1 konular ve ilan ettikleri deklarasyonlar, üç ülkenin ortak paydalarına dair oldukça açıklayıcı bir referans noktası oluşturabilir.

61 "Air Force Lauds Iniohos Exercise," Kathimerini, 13 Nisan 2019, https://www. ekathimerini.com/239540/article/ekathimerini/news/air-force-lauds-iniohos-exercise, Son erişim: 22 Ekim 2020.

62 "Blue Flag 2019: 40 Jets, 800 Personnel Attend IAF's Most Advanced Drill," The Jerusalem Post, 14 Kasim 2019, https:/www.jpost.com/israel-news/blue-flag-201940-jets-800-personnel-attend-iafs-most-advanced-drill-607870, Son erişim: 26 Ekim 2020 . 
Üç ülkenin 28 Ocak 2016 tarihinde gerçekleştirdiği ilk zirve oldukça önemlidir. GKRY'nin başkenti Lefkoşa'da gerçekleştirilen görüşmede, üçlünün arasındaki ilişkilerin geliştirilmesi noktasında uzlaşıya varılmıştır. Başbakan Netanyahu'nun burada yaptı̆̆ konuşma, söz konusu ilişkilerin gidişatına dair oldukça güçlü mesajlar barındırmaktadır. Bu bağlamda Netanyahu, ortak çıkarlardan da önce ortak değerlere yönelik bir vurgu yapma ihtiyacı hissetmiştir. Üç ülkenin çoğulculuk ve çeşitlilik gibi değerleri barındıran demokrasiler olduklarını iddia eden Netanyahu, söz konusu değerlerin ortak bir payda yaratması noktasında işlevsel olduğunun altını çizmiş olmaktadır. ${ }^{63}$

Ayrıca bu buluşmanın sonuç bildirgesi mahiyetinde bir deklarasyon da yayınlanmış ve üç ülke bu metinde, üzerinde uzlaşıya vardıkları ortak hareket alanlarını ifade etmişlerdir. Bu bağlamda, özellikle enerji alanındaki işbirliği potansiyelinin bu deklarasyonda da ifade edildiği vurgulanmalıdır. Doğu Akdeniz Boru Hattı olarak isimlendirilebilecek projelere açık olunduğu, bu minval üzere geliştirilecek projelerle enerji arz güvenliğinin tesis edilebileceği ve bölgesel işbirliği ve istikrara katkı sağlayacağı ifade edilmektedir. Böylece Türk tarafının tezleri hilafina, İsrail-YunanistanGKRY üçlüsü ortak projeleri gündemlerine aldıklarını teyit etmişlerdir.

Söz konusu zirvenin deklarasyonunda yer alan güvenlikle alakalı ifadeler ise oldukça enteresandır. Ocak 2016'da yapılan bu zirveye kadar geçen sürede çok defa ortak askeri tatbikat yapmış olan ülkeler, bu minvaldeki gelişmeleri yok sayarak ve deklarasyon metninde anmayarak, askeri işbirliklerinin hedefi noktasında kafa karıştırmak ister gibi görünmektedirler. Güvenlik bağlamında kullanılan ifadelerle üç ülke; terörizmi, yabancı savaşçıların sınırlar ötesi transferlerini, terörist gruplara finansal ve askeri destek veren odakları hedef almaktadır. ${ }^{64}$ Lakin üç ülkenin Doğu Akdeniz'de bugünlere kadar gerçekleştirdikleri ortak askeri tatbikatlara dair tek bir ifade dahi bulunmamaktadır.

8 Aralık 2016'da ikincisi gerçekleştirilen üçlü zirvede Başbakan Netanyahu'nun açıklamalarıyla resmi kayıtlara geçmiş ortak acil müdahale

\footnotetext{
63 “Trilateral Meeting Between Israel, Greece and Cyprus," Israel Ministry of Foreign Affairs, Son erişim: 17 Ekim 2020, https://mfa.gov.il/MFA/PressRoom/2016/Pages/ Trilateral-meeting-between-Israel-Greece-and-Cyprus-28-Jan-2016.aspx.

64 Israel Ministry of Foreign Affairs, "Trilateral Meeting."
} 
gücü oluşturulmasına yönelik ifadeler, üç ülkenin güvenlik odaklı gelişim seyri izleyen ilişkileri için oldukça erken örneklerden birisidir. $\mathrm{Bu}$ bağlamda Başbakan Netanyahu, Doğu Akdeniz bölgesi özelinde üç ülkenin askeri birliklerinden oluşturulacak bir acil müdahale gücünün kurulması, bu birliğin sadece kriz durumlarında sınırlı olmamak kaydıyla kalıcı bir statü kazanması ve bu gücün belli bir lokasyonda konuşlanmış bir komuta merkezi olması gereğini ifade etmiştir. ${ }^{65}$

İsrail ve GKRY'deki yangınlara yapılan ortak müdahale sonrası gelişen söz konusu fikirler, Netanyahu'nun 1srarlı vurgularına rağmen, ortak deklarasyonda yer almamıştır. Bu açıdan bakıldığında, sabit bir komuta merkezi olan ortak bir acil müdahale gücünün tesisi noktasında görüş ayrılıkları olduğu aşikardır. ${ }^{66}$

$\mathrm{Bu}$ toplantının deklarasyonunda yer alan güvenlik başlıklı ifadelerde ise geniş bir tanım tercih edilmiş ve üç ülkenin terörizm alanında işbirliği yapmasından bahsedilmiştir. $\mathrm{Bu}$ bağlamda, terörizme karşı mücadelede uluslararası toplumla da entegre bir vaziyet alınması gerektiği ifade edilmiştir. ${ }^{67}$

15 Haziran 2017 tarihinde Selanik'te yapılan üçlü zirvenin sonunda da ortak bir bildiri yayınlanmıştır. Bu bildiri kapsamında, belki de üçlü ilişkilerin bu tarihten sonraki gidişatına da yoğun etkide bulunacak en önemli gelişmelerden birisi olarak, Doğu Akdeniz Gaz Boru Hattı projesinin hayata geçirilmesinin güçlü bir biçimde desteklendiği ifade edilmiştir. ${ }^{68} \mathrm{Bu}$ projenin hayata geçirilmesiyle hedeflenen olgu ise Doğu Akdeniz'de hem İsrail'in hem de GKRY'nin keşfettiği enerji rezervlerini direkt olarak Yunanistan ve İtalya üzerinden Avrupa pazarlarına sunmaktır. Böylece yeni ve bağımsız bir güzergah inşa edilerek, Türkiye'nin süreçten

65 "PM Netanyahu, Cypriot President Anastasiades and Greek PM Tsipras Hold Trilateral Summit," Israel Ministry of Foreign Affairs, Son erişim: 23 Ekim 2020, https://mfa. gov.i1/MFA/PressRoom/2016/Pages/PM-Netanyahu-Cypriot-Pres-Anastasiades-andGreek-PM-Tsipras-hold-trilateral-summit-8-December-2016.aspx.

66 "Israel-Greece-Cyprus Trilateral Summit Declaration," Onisilos, 8 Aralık 2016, https://www.onisilos.gr/?p=3213, Son erişim: 23 Ekim 2020.

67 Onisilos, "Israel-Greece-Cyprus."

68 "Joint Declaration of Greece-Cyprus-Israel Trilateral Summit," Israel Ministry of Foreign Affairs, Son erişim: 17 Ekim 2020, https://mfa.gov.il/MFA/PressRoom/2017/ Documents/IsraelGreeceG2GJointDeclaration.pdf. 
dışlanması mümkün olacaktır. Elbette bahsi geçen proje, hem maliyeti hem de güvenlik açikları sebebiyle oldukça eleştirilmiştir.

8 Mayıs 2018'de Lefkoşa'da düzenlenen dördüncü üçlü zirve, yine benzer bir minval üzere gelişmiş ve üç ülke arasındaki enerji işbirliğinin potansiyelini ve olası projeleri öne çıkaran bir seyir izlemiştir. $\mathrm{Bu}$ bağlamda Yunanistan Başbakanı Tsipras'ın zirveye ilişkin yaptığ değerlendirmeler, tam olarak bu bağlamı doğrular niteliktedir. Başbakan Tsipras, üç ülke arasındaki gerçekleşmesi olası enerji projelerinin oldukça önemli olduklarını belirtmiş ve bu projelerin Doğu Akdeniz'de jeopolitik bir dönüşüme hizmet ettiklerini vurgulamıştır. ${ }^{69} \mathrm{Bu}$ noktada da tekrar gözlemlenen husus, üç ülkenin arasında gelişen güvenlik odaklı işbirliğinin bir şekilde perdelenmesidir. Enerji diplomasisi alanındaki gelişmeler, üç ülkenin ilişkilerindeki militarist boyutu perdelemeye yaramaktadır.

Fakat şurası da açıktır ki bu tarih itibariyle üç ülke, güvenlik alanındaki işbirliklerini siyasi bir zeminde de tartışmaya başladıklarını ifade eden ve bu durumu olumlayan tavırlar almışlardır. Bu bağlamda, ilki Kasım 2017'de gerçekleşen savunma bakanları toplantısına ${ }^{70}$ yönelik olumlu mesajlar deklarasyona da yansıtılmış ve üç ülke ilişkilerinin militarist doğası da bir biçimde kabul edilmiştir. Daha sonra da ikincisi Haziran 2018'de Lefkoşa'da düzenlenen savunma bakanları üçlü zirvesinin devamlılık arz etmesi, aslında üç ülke arasındaki ilişkilerin gerçek hüviyetine yönelik bir referans noktası da oluşturmuştur. ${ }^{71}$

Üç ülkenin beşinci buluşması olarak 20 Aralık 2018'de İsrail'in Berşeva kentinde gerçekleştirilen toplantı, savunma ve ulusal güvenlik ile ilgili konularda yine yüzeysel bir tutum belirlemiş̧tir. Bu bağlamda, terörizme özel bir vurgu yapılarak, bu konu üzerine yapılan ve yapılacak olan üçlü toplantılara dikkat çekilmiştir. ${ }^{72}$

69 "EastMed and EuroAsia Interconnector are Flagship Projects," The Prime Minister's Office of Greece, Son erişim: 25 Ekim 2020, https://primeminister.gr/ en/2018/05/08/19877.

70 "First Meeting of Cyprus, Greece and Israel Defense Ministers," Parikiaki, 7 Kasim 2017, http://www.parikiaki.com/2017/11/first-meeting-of-cyprus-greece-and-israeldefence-ministers/, Son erişim: 25 Ekim 2020.

71 "Trilateral Defense Summit Stresses Israel, Cyprus and Greece's Will to Enhance Security in Region," Parikiaki, 23 Haziran 2018, http://www.parikiaki.com/2018/06/ trilateral-defence-summit-stresses-israel-cyprus-and-greeces-will-to-enhancesecurity-in-region/, Son erişim: 25 Ekim 2020.

72 "Israel-Cyprus-Greece 5th Trilateral Summit Declaration," Hellenic Republic Greece in Israel, Son erişim: 26 Ekim 2020, https://www.mfa.gr/missionsabroad/en/israel-en/ 
$\mathrm{Bu}$ zirvenin önemli bir sonucu ise GKRY'nin teklifiyle Lefkoşa'da kurulması kararlaştırılan Daimi Sekretarya'dır. ${ }^{73}$ Söz konusu sekretarya, üçlü ilişkilerin kurumsallaşması noktasında oldukça önemli bir mihenk taşı olarak da görülebilir.

20 Mart 2019 tarihinde Kudüs'te gerçekleştirilen toplantıda ise İsrail, Yunanistan ve GKRY'ye ek olarak, ABD Dışş̧leri Bakanı Mike Pompeo da zirveye katılmış ve Amerikan yönetiminin bölgede oluşan İsrailYunanistan-GKRY aksını destekleyici bir tutum takındığını vurgulamıştır. $\mathrm{Bu}$ bağlamda gerçekleştirilen toplantıda, bölgesel işbirliğinin ve enerji güvenliğinin öneminin altı çizilerek, bölgesel istikrar ve güvenliğe yönelik kaygılar da ifade edilmektedir. ${ }^{74}$ Böylece Amerikan yönetimi, İsrail'in militarist minvalde yürüttüğü ve askeri işbirliklerinden ibaret bir süreci desteklediğini açıklamış olmaktadır.

19 Aralık 2019 tarihinde onaylanan "Doğu Akdeniz Güvenliği ve Enerji Ortaklığı Yasası” isimli bir yasayla ABD’nin Doğu Akdeniz'de gelişen İsrail-Yunanistan-GKRY eksenine desteği de somutlaşmıştır. Bu bağlamda ABD; GKRY'ye yönelik silah ambargosunu kaldırmay1, söz konusu üçlüyle ilişkilerini düzenleyecek bir Doğu Akdeniz Enerji Merkezi kurmayı, Yunanistan'a dış askeri yardımda bulunmayı ve ayrıca Yunanistan ve GKRY'ye Uluslararası Askeri Eğitim yardımını vaat etmiştir. ${ }^{75}$ Böylece Amerikan yönetimi, İsrail-Yunanistan-GKRY arasında olgunlaşan ilişkileri desteklediğini bir yasa vasıtasıyla tekrar deklare etmiş ve hatta diş politikasını bu bağlamda kalibre etmeyi tercih etmiştir.

2 Ocak 2020 itibariyle ise İsrail-Yunanistan-GKRY arasında Doğu Akdeniz Boru Hattı'na yönelik olarak anlaşma imzalanmıştır. Bu anlaşma uyarınca, yaklaşık olarak 1900 kilometre uzunluğunda bir boru hattının

news/israel-cyprus-greece-5th-trilateral-summit-declaration-beersheba-december20th-2018.html.

73 Hellenic Republic Greece in Israel, "Israel-Cyprus-Greece."

74 "Joint Declaration Between Cyprus, Greece, Israel and United States After the Sixth Trilateral Summit," U.S. Department of State, Son erişim: 22 Ekim 2020, https://www. state.gov/joint-declaration-between-cyprus-greece-israel-and-the-united-states-afterthe-sixth-trilateral-summit/.

75 "Congress Passes Menendez-Rubio Bill Reshaping U.S. Policy in Eastern Mediterranean," United States Senate Committee on Foreign Relations, Son erişim: 26 Ekim 2020. https://www.foreign.senate.gov/press/ranking/release/congress-passesmenendez-rubio-bill-reshaping-us-policy-in-eastern-mediterranean_-. 
İsrail-GKRY deniz yetki alanlarından başlayarak, Girit'e ve oradan da Yunanistan üzerinden İtalya'ya ulaştırılması hedeflenmektedir. ${ }^{76}$ Söz konusu boru hattına yönelik olarak uzun bir süredir dillendirilen eleştiriler, bu anlaşmayla birlikte görmezden gelinmiştir. Denizin altından gidecek olan boru hattı, maliyetleri ve güvenlik risklerini fazlasıyla yükseltecek bir uzunluktadır. Lakin bu durum, üçlünün boru hattı projesi konusundaki fikrini değiştirmemiş gözükmektedir.

Fakat bu nokta itibariyle, vurgulanmas1 gereken daha kritik bir husus vardır. Bu makalenin de iddia ettiği üzere, üçlü arasındaki ilişkilerin enerji diplomasisi ve işbirliğine dayandığı iddialarının yersizliği, söz konusu anlaşmanın tarihi ve bu tarihe kadar yapılan ortak askeri tatbikatlar ve girişimlerden anlaşılabilmektedir. Bir diğer ifadeyle, Doğu Akdeniz Boru Hattı'na yönelik anlaşmanın imzalandığı 2020 yılına kadar İsrail-Yunanistan-GKRY arasında çok sayıda askeri tatbikat ve temas gerçekleşmiştir. Bu durum da göstermektedir ki üç ülkenin ilişkilerine esas rengini veren husus, askeri ilişkiler ve dolayısıyla militarizmdir.

\section{Sonuç}

$\mathrm{Bu}$ çalışmada iddia edildiği üzere, İsrail'in Doğu Akdeniz politikası kapsamında Yunanistan-GKRY ile olan ilişkilerinde militarist bir yoğunlaşmanın olduğu gözlemlenebilmektedir. Üç ülkenin ilişkilerinde askeri sektördeki gelişmelerden başka somut bir gelişme neredeyse görülmemektedir. Her ne kadar devletler dış politikalarının merkezine ulusal güvenlikçi perspektifler yerleştirebilirlerse de İsrail'in Doğu Akdeniz politikasında biraz farklı bir görünüm söz konusudur.

İsrail'in Doğu Akdeniz politikası, ekseriyetle enerji diplomasisi başlığı altında gelişme göstermiştir. En azından kamuoyunu ikna etme sürecinin yapıtaşı olarak Doğu Akdeniz'de keşfedilen enerji yatakları, İsrail dış politikasının militarize içeriğini perdelemektedir. Bu bağlamda özellikle ikili ve üçlü zirveler incelendiğinde açık bir şekilde görülebilir ki üç ülke, askeri ilişkilerini ifade etmekten imtina etmektedirler. Bu durum, süreç

76 "Greece, Israel, Cyprus Sign EastMed Gas Pipeline Deal," Reuters, 2 Ocak 2020, https://www.reuters.com/article/us-greece-cyprus-israel-pipeline-idUSKBN1Z10R5, Son erişim: 26 Ekim 2020. 
ilerledikçe normalleşerek ancak 2020 y1lındaki zirvelerde ifadesi mümkün olabilmiştir. ${ }^{77}$ Halbuki bu çalışmanın da ortaya koyduğu üzere, üç ülkenin ilişkilerini neredeyse tamamıyla askeri ilişkiler oluşturmaktadır.

Bu durumun bir diğer göstergesi de üç ülke siyasetçilerinin toplantılarından anlaşılabilir. Üç ülke savunma bakanlarının toplantı sayısıyla, dışişleri bakanlarının toplantı sayıları arasında belirgin bir fark vardır. Hatta Ocak 2020'ye kadar olan süreçte dışişleri bakanlarının zirve biçiminde toplantı yaptıkları görülmemiştir. Aksine savunma bakanları, bu tarihe kadar defalarca buluşmuş ve ortak zirveler düzenlemiştir. Bu bağlamda da İsrail'in Doğu Akdeniz politikasında askeri ilişkilerin üstünlüğü özellikle belirtilmelidir.

Halbuki hemen her akademik ve popüler yayında da görülebileceği üzere, İsrail' in Yunanistan-GKRY ikilisi ile ilişkileri uzun zamandır "ittifak" kavramıyla tanımlanmaktadır. Ayrıca yine çoğu akademik ve popüler yayında rastlanabilecek olan iddia, İsrail'in Yunanistan-GKRY ikilisiyle geliştirdiği ilişkilerin ekseriyetle Türkiye "tehdidini”" dengelemek amacıyla hayata geçirildiğidir.

Bu bağlamda değerlendirilecek olursa, "ittifak" kavramıyla tanımlanan üçlü arasındaki ilişkiler, kavramın semantik-pratik sınırları itibariyle, ilişkilerin askeri doğasını açık etmektedir. Bir diğer ifadeyle, "ittifak" olarak isimlendirilen üçlü ilişkiler, öncelikle askeri bir zeminde tanımlanıyor demektir. Kaldı ki Türkiye'yi bir "tehdit" olarak algılayan ve tehdit dengeleme teorileriyle açıklanan üçlünün ilişkileri, böylelikle gerçekçi bir zemine oturabilir. Kısacası üç ülkenin ilişkileri, Türkiye "tehdidinin" yarattığı auraya bir reaksiyon olarak, "doğal olarak" askeri bir zeminde gelişmektedir. İsrail dış politikasının militarize statüsü, bu minvalde de tasdik edilmiş olmaktadır.

İsrail-Yunanistan ilişkilerindeki yapısallık, oldukça kayda değerdir. $\mathrm{Bu}$ bağlamda değerlendirilirse, iki ülkenin yakınlaşma sürecinde İsrail'de siyasetin merkezini Başbakan Netanyahu temsil ederken Yunanistan'da liderlik sürekli el değiştirmiştir. Farklı ideolojik pozisyonları temsil eden liderlerin yönetiminde Yunanistan, İsrail'le olan ilişkilerine yapısallık

77 "Israel-Greece Prime Minister's Summit Declaration," Hellenic Republic Ministry of Foreign Affairs, Son erişim: 22 Ekim 2020, https:/www.mfa.gr/en/current-affairs/ statements-speeches/israel--greece-prime-ministers-summit-declaration.html. 
atfederek, partiler-üstü bir konum kazandırmıştır. Bir başka açıdan bakıldığında, söz konusu ilişkilerin güçlenerek devam etmesinin en belirgin destekçisi kuşkusuz Başbakan Netanyahu'dur. Bu durumun, Doğu Akdeniz'deki güç dengelerinin dönüşümüyle ve Türkiye-İsrail ilişkilerindeki çöküşle alakalı olduğu iddia edilebilir.

İsrail dış politikasında militarizmin bir örneği olarak ele alınan Doğu Akdeniz politikası, elbette ki tekil bir örnek değildir. İsrail'in diş politika söylem ve pratiğinin önemli bir boyutunu temsil eden söz konusu militarizm, bizatihi İsrail'in niteliklerinden kaynaklanıyor görünmektedir.

İlk olarak İsrail, bölgesindeki kayda değer askeri güçlerden biridir. Ortadoğu siyasal tarihi boyunca edindiği askeri başarıları, yakın çevresiyle kıyaslamalı olarak nitelikli ve ileri teknoloji kapasitesiyle İsrail ordusu, Ortadoğu ve Doğu Akdeniz'de dikkat çekici bir güç olarak sivrilmektedir. Bir diğer neden olarak, İsrail'le ortak askeri politikalar belirlemenin, ilgili ülkeler nezdinde farklı anlamları da mevcuttur. Önceki bölümlerde de ifade edildiği üzere, İsrail'le olası askeri işbirlikleri, başta ABD ve NATO ülkeleriyle de yakınlaşmayı beraberinde getirmektedir. $\mathrm{Bu}$ bağlamda, Yunanistan'ın İsrail'le yakınlaşma sürecine paralel biçimde yürüyen ABD ile yakınlaşması, dikkatlerden kaçmamalıdır. Son olarak da İsrail'in militarize dış politika uygulamaları, elbette ki ulusal düzeydeki yaklaşımların da bir eseridir. Kadim sosyolojik bir travma olarak "Yahudi sürgününün" ve en yakın örneğiyle Yahudi soykırımının günümüzde dahi oldukça stratejik bir referans objesi olduğu unutulmamalıdır.

Sonuç olarak, İsrail dış politikasındaki ulusal güvenlik tahakkümü, neredeyse her alanda kendisini göstermektedir. Doğu Akdeniz politikasının incelendiği bu çalışmada ortaya konulanlar ışığında denilebilir ki İsrail, kendisine yönelik eleştirel tonlu "garnizon devlet" yakıştırmalarını fazlasıyla hak eden bir profile sahiptir. Dış politikasında yaşanan hemen her gelişme bir biçimde askeri ortaklıklara ve işbirliklerine evrilmektedir. Bizatihi iç siyasetinde de benzer bir durumun vaki olduğu ve sivil-asker ilişkilerinin girift bir nitelik arz ettiği göz önünde bulundurulursa, İsrail'in dış politikasına da doğal olarak yansıyan bu niteliği, elbette ki farklı alanlardaki politikalarının incelenmesine yönelik akademik motivasyonu da güçlendirmektedir. 


\section{Kaynakça}

Abadi, Jacob. Israel's Quest for Recognition and Acceptance in Asia: Garrison State Diplomacy. Londra: Frank Cass, 2004.

Ağdemir, Murat. "Relations Between Israel and the South Cyprus Greek Administration: A New Alignment in the Eastern Mediterranean?." Perceptions XXI, no. 2 (Yaz 2016): 103-26.

Baldwin, David A. "Security Studies and the End of the Cold War." World Politics 48, no. 1 (Ekim 1995): 117-41.

Bengio, Ofra. The Turkish-Israeli Relationship: Changing Ties of Middle Eastern Outsiders. New York: Palgrave Macmillan, 2004.

Brenner, Lenni. The Iron Wall: Zionist Revisionism from Jabotinsky to Shamir. Londra: Zed Books, 1984.

Buzan, Barry, Ole Weaver ve Jaap De Wilde. Security: A New Framework for Analysis. Colorado: Lynne Rienner, 1998.

Cox, Michael, Timothy J. Lynch ve Nicholas Bouchet. US Foreign Policy and Democracy Promotion: From Theodore Roosevelt to Barack Obama. New York: Routledge, 2013.

Ersoy, Tuğçe. "Emerging Alliances, Deteriorating Relations: Turkey, Israel and Greece in the Eastern Mediterranean." içinde Contemporary Israeli-Turkish Relations in Comparative Perspective, Editörler: Ayşegül Sever ve Orna Almog, 101-39. Cham: Palgrave Macmillan, 2019.

Inbar, Efraim. "Jerusalem's Decreasing Isolation: Israel in the World." Middle East Quarterly, (İlkbahar 2013): 27-38.

Kimmerling, Baruch. "Patterns of Militarism in Israel." European Journal of Sociology 34, no. 2 (1993): 196-223.

Leffler, Melvyn P. Safeguarding Democratic Capitalism: U.S. Foreign Policy and National Security 1920-2015. New Jersey: Princeton University Press, 2017.

Morin, Jean Frederic ve Jonathan Paquin. Foreign Policy Analysis: A Toolbox. Cham: Palgrave Macmillan, 2018. 
Navon, Emmanuel. "From Kippur to Oslo: Israel's Foreign Policy, 19731993.” Israel Affairs 10, no. 3 (2004): 1-40.

Neack, Laura. Studying Foreign Policy Comparatively: Cases and Analysis. Maryland: Rowman \& Littlefield, 2019.

Nye, Joseph S. "Soft Power." Foreign Policy, no. 80 (Sonbahar 1990): 153-71.

Papaioakeim, Marinos. "The Rise of the Cyprus' Defence Diplomacy in its Neighbourhood." The Cyprus Review 30, no. 1 (Ilkbahar 2018): 95112.

Samaan, Jean-Loop. The East Mediterranean Triangle at Crossroads. U.S.: Strategic Studies Institute and U.S. Army War College Press, 2016.

Schiff, Rebecca L. "Civil-Military Relations Reconsidered: Israel as an “Uncivil” State.” Security Studies 1, no. 4 (1992): 636-58.

Shindler, Colin. The Rise of the Israeli Right: From Odessa to Hebron. New York: Cambridge University Press, 2015.

Shlaim, Avi ve Avner Yaniv. "Domestic Politics and Foreign Policy in Israel," International Affairs 56, no. 2 (İlkbahar 1980): 242-62.

Shlaim, Avi. "The Oslo Accord." Journal of Palestine Studies 23, no. 3 (İlkbahar 1994): 24-40.

Simpson, Dwight J. “Israel: A Garrison State.” Current History 58, no. 341 (Ocak 1970): 1-6.

Sprinzak, Ehud. "Netanyahu's Safety Belt." Foreign Affairs 77, no. 4 (Temmuz-Ağustos 1998): 18-28.

Stavris, George. "The New Energy Triangle of Cyprus-Greece-Israel: Casting a Net for Turkey?" Turkish Policy Quarterly 11, no. 2 (Yaz 2012): 87-102.

Taraki, Lisa. "The Islamic Resistance Movement in the Palestinian Uprising." Middle East Report, no. 156 (Ocak-Şubat 1989): 30-2.

Tayfur, M. Fatih. "Dış Politika." içinde Devlet ve Ötesi: Uluslararası İlişkilerde Temel Kavramlar, Editör: Atila Eralp, 73-107. İstanbul: İletişim Yayınları, 2007. 
Tziampiris, Aristotle. The Emergence of Israeli-Greek Cooperation. Londra: Springer, 2015.

Tziarras, Zenonas. "Israel-Cyprus-Greece: A 'Comfortable' QuasiAlliance.” Mediterranean Politics 21, no. 3 (2016): 407-27.

Wolfers, Arnold. "'National Security” as an Ambiguous Symbol." Political Science Quarterly 67, no. 4 (Aralık 1952): 481-502.

\section{İnternet Kaynakları}

"A Mild Stroke Sends Sharon to the Hospital." The New York Times, 19 Aral1k 2005. https://www.nytimes.com/2005/12/19/world/middleeast/ a-mild-stroke-sends-sharon-to-the-hospital.html. Son erişim: 29 Ekim 2020.

“Air Force Lauds Iniohos Exercise." Kathimerini, 13 Nisan 2019. https:// www.ekathimerini.com/239540/article/ekathimerini/news/air-forcelauds-iniohos-exercise. Son erişim: 22 Ekim 2020.

"AJC, HALC Mark Fifth Anniversary of Congressional Greece-Israel Alliance." Kathimerini, 10 May1s 2018. https://www.ekathimerini. com/228513/article/ekathimerini/community/ajc-halc-mark-fifthanniversary-of-congressional-greece-israel-alliance. Son erişim: 18 Ekim 2020.

"Armed Forces of Cyprus and Israel Conduct the Exercise 'OnesilosGedeon'.” Parikiaki, 20 Mart2017.http://www.parikiaki.com/2017/03/ armed-forces-of-cyprus-and-israel-conduct-the-exercise-onesilosgedeon/. Son erişim: 22 Ekim 2020.

"Assasination in Israel: The Overview; Rabin Slain After Peace Rally in Tel Avib; Israeli Gunman Held; Says He Acted Alone." The New York Times, 5 Kasim 1995. https://www.nytimes.com/1995/11/05/world/ assassination-israel-overview-rabin-slain-after-peace-rally-tel-avivisraeli.html. Son erişim: 29 Ekim 2020.

"Benim için Davos Bitti." Hürriyet, 30 Ocak 2009. https://www.hurriyet. com.tr/dunya/benim-icin-davos-bitti-10886978. Son erişim: 29 Ekim 2020. 
"Blue Flag 2019: 40 Jets, 800 Personnel Attend IAF's Most Advanced Drill.” The Jerusalem Post, 14 Kasim 2019. https://www.jpost.com/ israel-news/blue-flag-2019-40-jets-800-personnel-attend-iafs-mostadvanced-drill-607870. Son erişim: 26 Ekim 2020.

"Cyprus and Israel Complete Onisilos-Gideon Exercise." Gold News, 22 Ekim 2014. http://www.goldnews.com.cy/en/economy/cyprus-andisrael-complete-onisilos-gideon-exercise. Son erişim: 28 Ekim 2020.

"Cyprus and Israel Sign Deal Demarcating Sea Borders." Haaretz, 17 Aralık 2010, https://www.haaretz.com/1.5094734. Son erişim: 28 Ekim 2020.

"Dayan Pushed PM Meir to Consider Using Nuclear Weapons in 1973 War." The Times of Israel, 3 Ekim 2013. https://www.timesofisrael. com/dayan-pushed-pm-meir-to-consider-using-nuclear-weaponsin-1973/. Son erişim: 29 Ekim 2020.

"EastMed and EuroAsia Interconnector are Flagship Projects." The Prime Minister's Office of Greece, 8 Mayıs 2018. https://primeminister.gr/ en/2018/05/08/19877. Son erişim: 25 Ekim 2020.

"First Meeting of Cyprus, Greece and Israel Defense Ministers." Parikiaki, 7 Ekim 2017. http://www.parikiaki.com/2017/11/first-meeting-ofcyprus-greece-and-israel-defence-ministers/. Son erişim: 25 Ekim 2020.

"Greece, Israel, Cyprus Sign EastMed Gas Pipeline Deal." Reuters, 2 Ocak 2020. https://www.reuters.com/article/us-greece-cyprus-israelpipeline-idUSKBN1Z10R5. Son erişim: 26 Ekim 2020.

"HALC, AJC Join Forces in Effort to Bolster Cyprus Security, Halt Sale of F-35 Jets to Turkey." Kathimerini, 7 May1s 2018. https://www. ekathimerini.com/228354/article/ekathimerini/comment/halc-ajc-joinforces-in-effort-to-bolster-cyprus-security-halt-sale-of-f-35-jets-toturkey. Son erişim: 17 Ekim 2020.

"Israel Concludes Multinational Blue Flag Drill." Defence News, 29 Ekim 2015. https://www.defensenews.com/training-sim/2015/10/29/israelconcludes-multinational-blue-flag-drill/. Son erişim: 22 Ekim 2020.

"Israel Preps for Massive Air Drill with US, Greece, Italy." The Times of Israel, 6 Kasim 2013. https://www.timesofisrael.com/israel-toconduct-massive-air-drill-with-us-greece-italy/. Son erişim: 22 Ekim 2020 . 
"Israel Trained Against Russian-made Air Defense System in Greece: Sources." Reuters, 4 Aralık 2015. https://www.reuters.com/article/usmideast-crisis-israel-greece-idUSKBN0TN10G20151204. Son erişim: 26 Ekim 2020.

"Israel Woos Greece After Rift With Turkey." BBC, 16 Ekim 2010. https:// www.bbc.com/news/world-middle-east-11556442. Son erişim: 17 Ekim 2020.

"Israel, Cyprus Sign Defence Agreements - Reports." Globes, 10 Ocak 2012. https://en.globes.co.il/en/article-1000714277. Son erişim: 22 Ekim 2020.

"Israel, Greece Construct New Radar System on Crete, Report Says." Haaretz, 19 Mart 2019. https://www.haaretz.com/israel-news/israelgreece-constructing-new-radar-in-crete-report-says-1.7039210. Son erişim: 26 Ekim 2020.

"Israel-Greece-Cyprus Trilateral Summit Declaration." Onisilos, 8 Aralık 2016. https://www.onisilos.gr/?p=3213. Son erişim: 23 Ekim 2020.

"Israeli Commandos Head to Cyprus for Largest Land-Based Drill." The Jerusalem Post, 10 Haziran 2017. https://www.jpost.com/israelnews/israeli-commandos-head-to-cyprus-for-largest-land-baseddrill-496421. Son erişim: 22 Ekim 2020.

"Israeli Defense Industries in Talks with Greek Army." The Jerusalem Post, 12 Aral1k 2010. https://www.jpost.com/defense/israeli-defenseindustries-in-talks-with-greek-army Son erişim: 18 Ekim 2020.

"Israeli Military Offsets Turkey's Loss with Greece, Romania." Asbarez, 29 Eylül 2010. http://asbarez.com/85907/israeli-military-offsetsturkeys-loss-with-greece-romania/. Son erişim: 26 Ekim 2020.

"Netanyahu Says Israel's Annexation Plan of Occupied West Bank Suspended 'for Time Being'." Daily Sabah, 17 Ağustos 2020. https://www.dailysabah.com/world/mid-east/netanyahu-says-israelsannexation-plan-of-occupied-west-bank-suspended-for-time-being. Son erişim: 29 Ekim 2020.

“Netanyahu's Big Fat Greek Wedding.” Haaretz, 1 Temmuz 2011. https:// www.haaretz.com/1.5024702. Son erişim: 18 Ekim 2020. 
"Trilateral Defense Summit Stresses Israel, Cyprus and Greece's Will to Enhance Security in Region." Parikiaki, 23 Haziran 2018. http://www. parikiaki.com/2018/06/trilateral-defence-summit-stresses-israelcyprus-and-greeces-will-to-enhance-security-in-region/. Son erişim: 25 Ekim 2020.

"U.S. Says Israeli Exercise Seemed Directed at Iran." The New York Times, 20 Haziran 2008. https://www.nytimes.com/2008/06/20/ washington/20iran.html. Son erişim: 18 Ekim 2020.

Al Rantawi, Oraib. “The UAE Lie of 'Stopping' Israel's West Bank Annexation." Yedioth Ahronot, 12 Eylül 2020. https://www.ynetnews. com/article/SyVh9A74D. Son erişim: 29 Ekim 2020.

Belfer Center Special Report. Deterring Terror: How Israel Confronts the Next Generation of Threats. USA: Belfer Center, Ağustos 2016. https://www. belfercenter.org/sites/default/files/legacy/files/IDFDoctrineTranslation.pdf

Bilirakis, Gus M., ve Ted Deutch. "Hellenic-Israeli Partnership Strengthens Democracy." The Washington Times, 13 Şubat 2013. https://www. washingtontimes.com/news/2013/feb/13/bilirakis-and-deutchhellenic-israeli-partnership-/. Son erişim: 17 Ekim 2020.

European Union Official Website. "Foreign and Security Policy." Son erişim: 17 Ekim 2020. https://europa.eu/european-union/topics/ foreign-security-policy_en.

Hellenic Air Force. "Iniochos 2017 Exercise.” Son erişim: 26 Ekim 2020. https://www.haf.gr/en/2017/03/iniohos-2017-exercise/.

Hellenic Republic Greece in Israel. "Israel-Cyprus-Greece 5th Trilateral Summit Declaration.” Son erişim: 26 Ekim 2020. https://www.mfa.gr/ missionsabroad/en/israel-en/news/israel-cyprus-greece-5th-trilateralsummit-declaration-beersheba-december-20th-2018.html.

Hellenic Republic Ministry of Foreign Affairs. "Israel-Greece Prime Minister's Summit Declaration." Son erişim: 22 Ekim 2020. https:// www.mfa.gr/en/current-affairs/statements-speeches/israel--greeceprime-ministers-summit-declaration.html.

Israel Ministry of Foreign Affairs. "Joint Declaration of Greece-CyprusIsrael Trilateral Summit.”, Son erişim: 17 Ekim 2020. https://mfa.gov.il/ MFA/PressRoom/2017/Documents/IsraelGreeceG2GJointDeclaration. pdf. 
Israel Ministry of Foreign Affairs. "PM Netanyahu, Cypriot President Anastasiades and Greek PM Tsipras Hold Trilateral Summit." Son erişim: 23 Ekim 2020. https://mfa.gov.il/MFA/PressRoom/2016/ Pages/PM-Netanyahu-Cypriot-Pres-Anastasiades-and-Greek-PMTsipras-hold-trilateral-summit-8-December-2016.aspx.

Israel Ministry of Foreign Affairs. "Trilateral Meeting Between Israel, Greece and Cyprus." Son erişim: 17 Ekim 2020. https://mfa.gov.il/ MFA/PressRoom/2016/Pages/Trilateral-meeting-between-IsraelGreece-and-Cyprus-28-Jan-2016.aspx.

Levin, Geoffrey. “Ariel Sharon's Legacy of Separation.” The Atlantic, 11 Ocak 2014. https://www.theatlantic.com/international/archive/2014/01/ ariel-sharons-legacy-of-separation/282955/. Son erişim: 29 Ekim 2020.

Mekel, Arye. "Birth of A Geopolitical Bloc: The Israel-Greece-Cyprus Axis." Haaretz, 31 Ocak 2016. https://www.haaretz.com/israelnews/.premium-birth-of-a-geopolitical-bloc-the-israel-greece-cyprusaxis-1.5397833. Son erişim: 26 Ekim 2020.

The Knesset Official Website. Son erişim: 17 Ekim 2020. https:// main.knesset.gov.il/EN/mk/government/Pages/governments. aspx?govId $=35$.

Tzogopoulos, George N. "The Future of Greek-Israeli Relations." BESA Center Perspective Paper, no. 788, 8 Nisan 2018. Nisan 2018. https:// besacenter.org/perspectives-papers/greece-israel-relations/. Son erişim: 22 Ekim 2020.

U.S. Department of State. "Joint Declaration Between Cyprus, Greece, Israel and United States After the Sixth Trilateral Summit." Son erişim: 22 Ekim 2020. https://www.state.gov/joint-declaration-betweencyprus-greece-israel-and-the-united-states-after-the-sixth-trilateralsummit/.

United States Senate Committee on Foreign Relations. "Congress Passes Menendez-Rubio Bill Reshaping U.S. Policy in Eastern Mediterranean." Son erişim: 26 Ekim 2020. https://www.foreign. senate.gov/press/ranking/release/congress-passes-menendez-rubiobill-reshaping-us-policy-in-eastern-mediterranean_-. 
